Boston University School of Law

Scholarly Commons at Boston University School of Law

Faculty Scholarship

$2-2010$

\title{
End the Failed Chevron Experiment Now: How Chevron Has Failed and Why it Can and Should Be Overruled
}

Jack M. Beermann

Boston University School of Law

Follow this and additional works at: https://scholarship.law.bu.edu/faculty_scholarship

Part of the Administrative Law Commons

\section{Recommended Citation}

Jack M. Beermann, End the Failed Chevron Experiment Now: How Chevron Has Failed and Why it Can and Should Be Overruled, in 42 Connecticut Law Review 779 (2010).

Available at: https://scholarship.law.bu.edu/faculty_scholarship/516

This Article is brought to you for free and open access by Scholarly Commons at Boston University School of Law. It has been accepted for inclusion in Faculty Scholarship by an authorized administrator of Scholarly Commons at Boston University School of Law. For more information, please contact lawlessa@bu.edu. 


\title{
CONNECTICUT LAW REVIEW
}

\begin{abstract}
Article
End the Failed Chevron Experiment Now: How Chevron Has Failed and Why It Can and Should Be Overruled
\end{abstract}

\author{
JACK M. BEERMANN
}

In Chevron U.S.A., Inc. v. NRDC, decided in 1984, the Supreme Court announced a startling new approach to judicial review of statutory interpretation by administrative agencies, which requires courts to defer to agency interpretations of ambiguous statutes. Although it was perhaps hoped that Chevron would simplify judicial review and increase deference to agency interpretation, the opposite has occurred. Chevron has complicated judicial review and, at best, it is uncertain whether it has resulted in increased deference to agency interpretation. In fact, for numerous reasons, Chevron has been a failure on any reasonable measure and should be overruled. Further, overruling Chevron would be consistent with the practice of stare decisis because it is a judge-made rule, has proven unworkable in practice, is inconsistent with a governing statute, and has not spawned settled expectations that would be upset if it is overruled. Finally, the Chevron doctrine should be replaced either by reviving, with minor modifications, pre-Chevron practice, or with a slightly modified version of Skidmore deference. 


\section{Article ConTents}

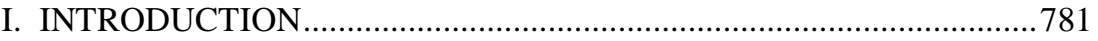

II. HOW CHEVRON HAS FAILED..........................................................

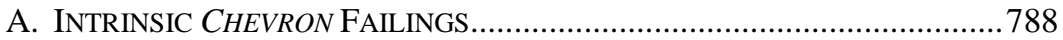

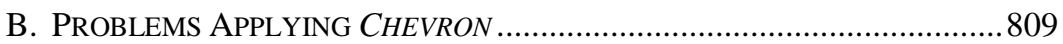

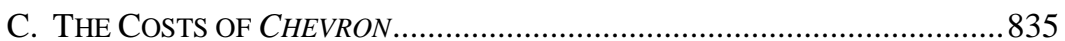

III. WHY IT WOULD BE ACCEPTABLE

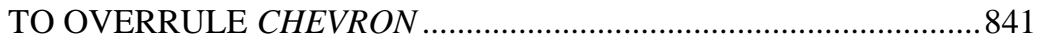

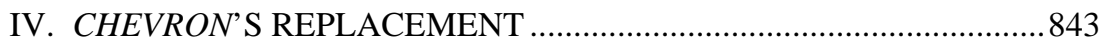

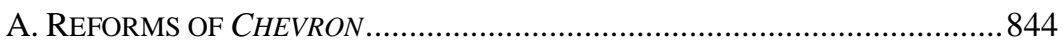

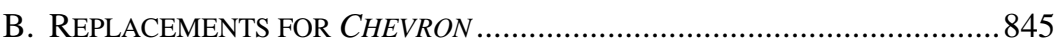

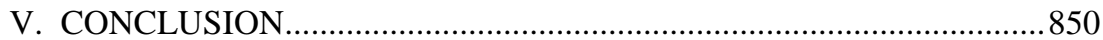

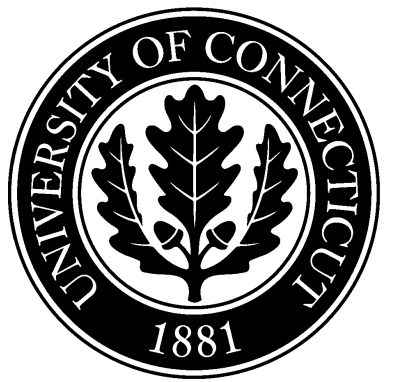




\title{
End the Failed Chevron Experiment Now: How Chevron Has Failed and Why It Can and Should Be Overruled
}

\author{
JACK M. BEERMANN ${ }^{*}$
}

\section{INTRODUCTION}

In Chevron U.S.A., Inc. v. NRDC, ${ }^{1}$ decided in 1984, the Supreme Court announced a startling new two-step approach to judicial review of statutory interpretation by administrative agencies, requiring courts to defer to agency interpretations of ambiguous statutes. ${ }^{2}$ Chevron stated that a statute is unambiguous only if Congress has directly spoken to the precise question at issue, which, if applied as written, means that a high proportion of statutes are likely to be found ambiguous. Once a statute is found to be ambiguous, Chevron requires the reviewing court to approve any reasonable or permissible construction. ${ }^{3}$ This standard appears to be very

${ }^{*}$ Professor of Law and Harry Elwood Warren Scholar, Boston University School of Law. (C) 2009, Jack M. Beermann, all rights reserved. The title is adapted from Justice Breyer's separate opinion in Morse v. Frederick, 551 U.S. 393, 432 (2007) (Breyer, J., concurring in the judgment in part and dissenting in part), in which Justice Breyer advocated eliminating the requirement, imposed in Saucier v. Katz, 533 U.S. 194 (2001), that federal courts deciding qualified immunity cases resolve the constitutional merits first. The Court heeded Justice Breyer's call in Pearson v. Callahan, $129 \mathrm{~S}$. Ct 808 (2009). Thanks to Bill Anderson, Ron Cass, Alan Feld, Mike Harper, Linda Jellum, Gary Lawson, and Richard Murphy for helpful comments and suggestions. Thanks also to David Rod and Michelle Kick, Boston University School of Law classes of 2011 and 2009, respectively, for excellent research assistance.

${ }^{1} 467$ U.S. 837 (1984).

${ }^{2}$ Some commentators have found the Chevron decision to represent a sharp break with past practice. See, e.g., Jonathan T. Molot, Reexamining Marbury in the Administrative State: A Structural and Institutional Defense of Judicial Power Over Statutory Interpretation, 96 Nw. U. L. REv. 1239, 1259 n.78 (2002) (“Although Chevron was drafted to appear more as an evolution than a revolution in the Court's thinking there can be no serious doubt that Chevron represented a significant shift in the Court's interpretive theory."); Sidney A. Shapiro \& Richard E. Levy, Judicial Incentives and Indeterminacy in Substantive Review of Administrative Decisions, 44 DUKE L.J. 1051, 1062 (1995) (describing Chevron as a "landmark decision[] that signaled a turning point in the substantive review of agency decisions"); William N. Eskridge, Jr. \& Lauren E. Baer, The Continuum of Deference: Supreme Court Treatment of Agency Statutory Interpretations from Chevron to Hamdan, 96 GEO. L.J. 1083, 1093 (2008) ("Chevron is often described as having revolutionized the jurisprudence of agency deference"). Merrill and Hickman point out that what was new about Chevron was the imposition of mandatory deference in cases of ambiguity and silence. Their reading of pre-Chevron case law was that mandatory deference existed only when Congress expressly delegated interpretive power. To them, Chevron greatly expanded the zone of mandatory deference. Thomas W. Merrill \& Kristen E. Hickman, Chevron’s Domain, 89 GEO. L.J. 833, 833-34 (2001).

${ }^{3}$ Chevron, 467 U.S. at 842-43. Chevron created what has become a well known two-step process. Under Step One, if the reviewing court determines that Congress's intent is clear, i.e., that Congress has directly spoken to the precise question at issue, Congress's clearly expressed intent 
deferential to agency interpretation. While the Court itself might not have intended to make great changes in administrative law, ${ }^{4}$ Chevron quickly became the iconic representation of a completely new way of reviewing agency interpretive decisions. ${ }^{5}$

Chevron is the most famous Supreme Court decision in the history of administrative law, and it also seems to be administrative law's most highly analyzed doctrine. ${ }^{6}$ It does not take much study, however, to reveal one basic fact about the Chevron doctrine: as a legal doctrine, it has proven to be a complete and total failure, and thus the Supreme Court should overrule it at the first possible opportunity.

This Article explains in detail how and why the Chevron doctrine has failed, and it also shows that it may and should be overruled. Part II addresses the "should"-why Chevron should be overruled; Part III addresses the "may"-why overruling Chevron would be consistent with the Supreme Court's principles of stare decisis; and Part IV of this Article presents an alternative framework for judicial review of agency statutory interpretation decisions that does not share Chevron's fatal defects.

In short, Chevron should be overruled for the following overlapping sets of reasons: ${ }^{7}$

1. Chevron is contrary to the statute that governs judicial review of statutory interpretation, 5 U.S.C. $\S 706$, so much so that the Court actually found it necessary to rephrase the statutory standard in the opinion to make the statute appear more deferential than the language passed by Congress.

governs regardless of the agency's views. However, if Congress's intent is not clear, i.e., if Congress has not directly spoken to the precise question at issue, then under Step Two, the reviewing court must defer to the agency's reasonable or permissible construction of the statute. Id.

${ }^{4}$ Others have observed, based on a review of Court papers from the time of the decision, that Justice Stevens may not have viewed his opinion as making any great change to the practice of judicial review in administrative law. As Tom Merrill has stated, "There is no evidence that Justice Stevens understood his handiwork in Chevron as announcing fundamental changes in the law of judicial review." Thomas W. Merrill, The Story of Chevron: The Making of an Accidental Landmark, in Administrative LaW StoriEs 398, 420 (Peter L. Strauss ed., 2006). Regardless of Justice Stevens's intent, the language of the opinion appears to create a radically more deferential standard of review for agency interpretations.

${ }^{5}$ See id. at 402.

${ }^{6}$ A Westlaw search of the JLR database conducted on August 6, 2009, returned 7287 documents citing Chevron either in the United States Reports or the Supreme Court Reporter. For comparison, a search for citations of another important administrative law decision in that database, Motor Vehicle Manufacturers Association of the U.S., Inc. v. State Farm Mutual Insurance Co., 463 U.S. 29 (1983), returned 1529 documents.

${ }^{7}$ This Article does not claim that the reasons given herein are the only reasons why Chevron should be overruled. There may be additional reasons why it would be better to abandon or significantly reform the Chevron framework. See Elizabeth V. Foote, Statutory Interpretation or Public Administration: How Chevron Misconceives the Function of Agencies and Why It Matters, 59 ADMIN. L. REV. 673, 675, 678 (2007) (arguing that the APA framework for judicial review works better than the Chevron framework because agencies are primarily engaged in policy-based public administration, rather than statutory interpretation). 
2. Chevron has no adequate theoretical foundation. It was built on a faulty premise concerning congressional intent and was (and is) contrary to established traditions concerning the distribution of authority in statutory interpretation cases, at least as embodied in many of the cases decided after the passage of the Administrative Procedure Act (“APA”).

3. The Chevron opinion was poorly constructed and unclear on basic issues such as the proper role of interpretation, legislative history, and policy arguments. It is still not clear whether Chevron concerns review of statutory interpretation or review of policy decisions.

4. A short time after establishing the Chevron doctrine, the Court created a new version of Step One, which allows the reviewing court to employ the "traditional tools of statutory interpretation" to determine whether Congress's intent is clear. ${ }^{8}$ This threw the doctrine into disarray and spawned three competing versions of Step One, leading to conflicting lines of cases. Currently, the application of the Chevron doctrine is highly unpredictable, and the decision itself is cited for opposing propositions.

5. For a variety of reasons, Chevron apparently has not had the desired effect of significantly increasing deference to agencies. The reasons for this failure are not altogether clear, but include, first, that Chevron is so pliable that courts applying it can still reach any desired result; second, that agencies may have become more adventurous in their statutory interpretation, leading to increased likelihood of rejection on judicial review; ${ }^{9}$ and third, that judges may be simply unwilling to defer to interpretations with which they disagree.

6. The Supreme Court does not even cite Chevron in a high proportion of the cases in which it arguably applies.

\footnotetext{
${ }^{8}$ The "traditional tools" language actually appeared in the Chevron opinion, but it was not until later that this language spawned an alternative, less deferential, version of Step One. See Chevron, 467 U.S. at 843 n.9 ("If a court, employing traditional tools of statutory construction, ascertains that Congress had an intention on the precise question at issue, that intention is the law and must be given effect.”).

${ }^{9}$ This reason may seem inconsistent with the prior claim that courts have not actually become more deferential to agencies. There is no question, however, that in many instances the invocation of Chevron has been accompanied by the promise of deference, which may mislead agencies into believing that their output will receive more deference on judicial review. This could actually lead to an increase in rejection of agency action. It is as if the police established speed traps in an area in which they announced they would engage in less intensive enforcement. Drivers misled by the signals from the authorities or overly optimistic about their ability to evade detection may continue to speed.
} 
Something is amiss when the Court does not find it necessary to employ the test that it created to govern a class of cases.

7. The Chevron decision created uncertainty about when it applies, making it necessary for the Court to construct a doctrine to determine just that. This doctrine, referred to as Chevron Step Zero, is even more uncertain than the Chevron doctrine itself.

8. All of the uncertainty, noted above, surrounding the application of Chevron and when it applies has forced the Justices and parties to expend inordinate resources arguing over the Chevron doctrine instead of what they should be arguing about, Congress's intent and the rationality of agency policy in the particular case. In short, the litigation costs surrounding Chevron appear to outweigh any benefits the doctrine may have created.

9. Chevron encourages irresponsible agency and judicial behavior. Agencies expecting that their interpretive decisions will be reviewed under a deferential version of Chevron are free to disregard congressional intent and impose their own policy views even when it is possible to have at least a good sense of how Congress would have wanted the agency to act. Reviewing courts can brush off serious challenges to agency decisions by invoking Chevron without engaging whether the agency is thwarting imperfectly expressed congressional intent.

10. Consensus on the proper understanding and application of the Chevron framework is unlikely in the foreseeable future. In addition to the reasons for the indeterminacy of the Chevron doctrine discussed above, the unlikelihood of this changing is evidenced by the facts that, despite appearances, there is no stable constituency on the Court for Chevron deference and the scholarly commentary on Chevron has not come to consensus on basic issues surrounding Chevron. In short, after twenty-five years of instability, there is no reason to believe that the Chevron framework is likely to become a stable decisionmaking process.

Chevron's multiple meanings make analysis of Chevron very difficult. In fact, a number of the criticisms raised in this Article may appear to be in conflict with each other. Some of the criticisms apply only when the reviewing court applies the original highly deferential version of Chevron under which Step One is very narrow and Step Two has virtually no teeth. 
Other criticisms apply to later versions of Chevron under which Step One has become very broad, with many cases resolved on the basis of clear congressional intent that does not meet the original standard of Congress having "directly spoken to the precise question at issue." Still other criticisms apply simply because the Court has not provided a methodology for choosing among the various versions of the Chevron framework and behaves as if Chevron has a single, clear meaning.

Multiple versions of Chevron can mislead agencies and courts. People often see what they want to see. Lower courts and agencies may seize on highly deferential versions of Chevron-courts to clear the docket and agencies to test the limits of statutory authority. Both may then be surprised when the Supreme Court employs a less deferential understanding of Chevron Step One to overrule an agency's statutory construction that had been approved on review by a lower court.

Overruling Chevron would also be consistent with the reasoning the Court has used in recent cases in support of the permissibility of overruling precedent within traditions of stare decisis. ${ }^{10}$ First, overruling Chevron would not upset settled expectations. ${ }^{11}$ This is especially true given that the application of Chevron is so unpredictable. No one rationally orders their affairs in reliance on Chevron deference. Second, Chevron is a judgemade rule that did not purport to be based on statutory interpretation that Congress might have relied upon in shaping the law. ${ }^{12}$ Third, experience with Chevron since it was decided shows that it is a failure. ${ }^{13}$ In other words, overruling Chevron would not merely be the result of changed views, but rather would be informed by experience that could not have been available at the time Chevron was decided. These factors confirm that overruling Chevron would be consistent with the principles that govern whether it is permissible for a court to overrule its precedent.

One issue that needs to be discussed is what it would mean for the Court to overrule Chevron since it represents a decision procedure rather than a rule of substantive law and may have little if any actual effect on the outcome of cases. On the first point, there is nothing odd about overruling a decision process or standard like the Chevron doctrine. The Court has, for example, changed the standard for evaluating free exercise claims without overruling any particular substantive decision, ${ }^{14}$ the Court has

\footnotetext{
${ }^{10}$ See Pearson v. Callahan, 129 S. Ct. 808, 817 (2009) (overruling the requirement imposed in Saucier v. Katz, 533 U.S. 194 (2001), that courts reach constitutional merits before determining whether civil rights defendants are immune).

${ }^{11}$ See Montejo v. Louisiana, 129 S. Ct. 2079, 2081 (2009) (that a decision that has proven unworkable is "a traditional ground for overruling it").

${ }^{12}$ See United States v. Gaudin, 515 U.S. 506, 521 (1995).

${ }^{13}$ See Planned Parenthood of Se. Pa. v. Casey, 505 U.S. 833, 854 (1992) (citing Swift \& Co. v. Wickham, 382 U.S. 111, 116 (1965)).

${ }^{14}$ Employment Div. v. Smith, 494 U.S. 872, 879, 883-85 (1990).
} 
adjusted the standards used to evaluate whether expert testimony is admissible, ${ }^{15}$ and the Court has made adjustments to the standards it uses to determine whether decisions or legislation should have retroactive effect. $^{16}$ The best argument against overruling Chevron is that it has no effect on the actual outcome of cases. Thus, it is not worth taking the trouble to overrule it. Even if that is all true, it supports overruling Chevron if for no other reason than to save the time and effort lawyers and judges devote to exploring the vagaries of the Chevron doctrine.

If Chevron is overruled, what should take its place? The way to answer this question is to refer to the APA: when a federal court conducts judicial review, it should decide all questions of law as the APA appears to direct. $^{17}$ This is not to suggest prohibiting reviewing courts from paying close attention to agency views, but the ultimate judicial decision should be based on what the court finds to be the best reading of the statute. ${ }^{18}$ If, however, genuine ambiguity leaves a range of potential meanings, the Court should return to pre-Chevron practice and determine whether the agency has interpreted the statutory provision in a reasonable manner, with attention to the meaning of the statute, its purpose and history, and the wisdom of its policy choices under the arbitrary, capricious standard. ${ }^{19}$ When an agency has been expressly granted power to create law, the reviewing court should, as in pre-Chevron practice, determine if the agency's interpretation is within the delegation of authority and passes muster under the arbitrary, capricious test.

Although questions of meaning are often bound up with policy decisions, the two should be separated as much as possible, and reviewing courts should review agency policy decisions under the applicable standard of review separately from questions of statutory meaning. For example, in Chevron itself, the Court should have separated the question of whether the bubble concept was linguistically consistent with the statutory phrase

\footnotetext{
${ }^{15}$ Daubert v. Merrell Dow Pharm., Inc., 509 U.S. 579, 585, 587-89 (1993).

${ }^{16}$ See Teague v. Lane, 489 U.S. 288, 299-301, 310 (1989); Chevron Oil Co. v. Huson, 404 U.S. 97, 105-07 (1971).

${ }^{17}$ See 5 U.S.C. § 702 (2006).

${ }^{18}$ This Article does not take a position on whether reviewing courts should use all of the traditional tools of statutory interpretation, including the canons of construction to arrive at the best interpretation. As many have observed over several decades, the canons are unreliable and manipulable, and thus using them could preserve or even augment the freedom courts have under Chevron. See, e.g., Karl N. Llewellyn, Remarks on the Theory of Appellate Decision and the Rules or Canons About How Statutes Are To Be Construed, 3 VAND. L. REV. 395, 401 (1950) (“[T]here are two opposing canons on almost every point. . . . [T] he construction contended for must be sold . . . by means other than the use of the canon.”).

${ }^{19}$ Practice under this standard would not differ from Chevron in one important respect-unless the court finds that a statute has only one permissible meaning, the agency should remain free to alter its interpretation within an allowable range. See Nat'l Cable \& Telecomm. Ass'n v. Brand X Internet Servs., 545 U.S. 967, 981 (2005). This is not inconsistent with the judicial obligation to determine the law because the court has found that the statute does not clearly decide which of a range of meanings represents the best understanding of congressional intent.
} 
"stationary source," from the question of whether adopting that meaning made regulatory sense. The former question should be reviewed de novo, while the latter question should be reviewed under the deferential arbitrary, capricious standard. ${ }^{20}$

The virtues of this approach are many. Review of agency statutory interpretation would be much simpler if the focus was on the meaning of the statute rather than on whether and how Chevron applies to the particular case. This would save litigation costs and force everyonecourts, challengers, and agencies-to focus on Congress's expressed intent, which ought to be the most important factor in statutory interpretation and application. Agencies would be less able to frustrate Congress's intent by hiding behind Chevron on judicial review. And most importantly, judicial review of agency statutory interpretation would be more consistent with governing constitutional and statutory principles.

Overruling Chevron may also have vices. Insofar as Chevron has made it simpler to dispose of at least a small category of cases-judicial review of rules issued under plainly ambiguous statutes-some cases may become more complicated to litigate and decide. This would lead to increased costs and might give some litigants more hope of prevailing than they might otherwise have had, which would encourage litigation. These effects might be especially likely if Chevron is more effective in lower courts than in the Supreme Court. Further, if one credits Chevron's argument that agency interpretation is preferable to interpretation by unaccountable federal judges, then overruling Chevron would have costs in terms of democratic accountability.

In sum, as the following analysis illustrates, although abandoning the Chevron doctrine might create problems, they are not severe enough to justify holding onto the failed Chevron standard. At a minimum, judgment should be reserved until Chevron can be compared with the replacement for the Chevron regime offered below.

Part II of this Article elaborates on how Chevron has failed. Part III elaborates on the permissibility of overruling Chevron. Part IV discusses what it would mean to overrule Chevron and proposes a replacement for the Chevron doctrine. Part V concludes.

${ }^{20}$ See Int'l Bhd. of Elec. Workers v. Interstate Commerce Comm'n, 862 F.2d 330, 335-36 (D.C. Cir. 1988) ("Our next task is to review the substance of the ICC's decision independent of questions of statutory authority. [A] question remains whether the agency's announced decision ... was 'arbitrary or capricious.'”). The Supreme Court has used language that appears to endorse this approach, but it has not actually engaged in arbitrary, capricious review of agency interpretations. See Household Credit Servs., Inc. v. Pfennig, 541 U.S. 232, 242 (2004) (“Because $§ 1605$ is ambiguous, the Board's regulation implementing $\S 1605$ 'is binding in the courts unless procedurally defective, arbitrary or capricious in substance, or manifestly contrary to the statute.' (quoting United States v. Mead Corp., 533 U.S. 218, 227 (2001))). 


\section{HOW CHEVRON HAS FAILED}

The ways in which Chevron has failed can be sorted into three rough and somewhat overlapping categories. The first category comprises Chevron's intrinsic failings, both the doctrine and the opinion. The second category involves problems that have arisen in the application of the Chevron doctrine. The third category involves the costs and benefits of the Chevron doctrine. As a fourth and related measure of Chevron's failings, this Article discusses the lack of any likelihood of consensus at the Court or in scholarly commentary surrounding Chevron. In short, the failure of Chevron as a credible legal standard is illustrated well by the fact that after twenty-five years, arguments persist in the cases and commentary over basic issues such as how many steps Chevron really has and whether Chevron represents a sensible decision process.

\section{A. Intrinsic Chevron Failings}

The first two of the enumerated reasons for overruling Chevron fall into the "intrinsic failings" category, namely that Chevron has no adequate theoretical foundation and that it is contrary to the statute that governs judicial review of agency action. ${ }^{21}$

\section{Chevron Seems Inconsistent with the APA}

The most startling thing about Chevron initially is that it appears inconsistent with the Administrative Procedure Act's ("APA") judicial review provisions. ${ }^{22}$ APA section 706 states that "the reviewing court shall decide all relevant questions of law, interpret constitutional and statutory provisions, and determine the meaning or applicability of the terms of an agency action." 23 In section 706(2), the statute provides that "[t]he reviewing court shall . . . hold unlawful and set aside agency action ... found to be (A) arbitrary, capricious, an abuse of discretion, or otherwise not in accordance with law[.]”24 These seem to be relatively clear statements by Congress intended to assign resolution of legal issues to reviewing courts, not to administrative agencies. As many courts, including the Supreme Court, have noted, the APA arose out of years of study and debate, and therefore its language should not be lightly

${ }^{21}$ The third reason that the Chevron opinion was poorly constructed and unclear on important issues straddles the first two categories of Chevron failings (intrinsic problems and problems in application). It fits better into the second category, and thus it is discussed there.

${ }^{22}$ I cannot hope to improve on John Duffy's explanation of how Chevron is inconsistent with the text and legislative history of the APA. See John E. Duffy, Administrative Common Law in Judicial Review, 77 TEX. L. REV. 113, 189-211 (1998).

${ }^{23} 5$ U.S.C. $\S 706$ (2006) (emphasis added).

${ }^{24}$ Id. (emphasis added). 
disregarded. $^{25}$

The legislative history also supports reading the APA as assigning primary responsibility for resolution of legal questions to the courts. As John Duffy has explained:

The first sentence of Section 706 of the APA requires a reviewing court to "decide all relevant questions of law" and to "interpret constitutional and statutory provisions." The legislative history of the APA leaves no doubt that Congress thought the meaning of this provision plain. As Representative Walter, Chairman of the House Subcommittee on Administrative Law and author of the House Committee Report on the bill, explained to the House just before it passed the bill, the provision "requires courts to determine independently all relevant questions of law, including the interpretation of constitutional or statutory provisions." Thus Justice Scalia, in championing Chevron, admits that the 79th Congress was laboring under "the quite mistaken assumption that questions of law would always be decided de novo by the courts." But if Congress enacted that assumption into law with Section 706, what power do the courts have to overturn the decision as "mistaken?"26

The APA's judicial review provisions should be understood in light of the politics surrounding the passage of the APA and the ebbs and flows of deference to agency legal decisions in the pre-APA period. The APA was the product of a hard fought political battle over the place of the agencies in the government and the future of New Deal policies. In George Shepherd's view, the administration largely won, with conservatives achieving only small reforms aimed at restraining agency behavior in the name of greater protection of individual rights. ${ }^{27}$ McNollgast adopts a similar view, with an interesting twist. ${ }^{28}$ They agree with Shepherd that the Democrats won the war, if not every battle, over the APA, but they disagree somewhat with Shepherd's conclusions on the politics of the

\footnotetext{
${ }^{25}$ See, e.g., Vt. Yankee Nuclear Power Corp. v. NRDC, 435 U.S. 519, 523, 547-48 (1978) (noting that the APA was a legislative enactment which settled "long-continued and hard-fought" contentions (citation omitted)); In re Lueders, 111 F.3d 1569, 1576 (Fed. Cir. 1997) (tracing the legislative history leading up to enactment of the APA).

${ }^{26}$ Duffy, supra note 22, at 193-94 (citations omitted); see also McNollgast, The Political Origins of the Administrative Procedure Act, 15 J.L. ECON. \& ORG. 180, 200 (1999) (“[C]ourts, not agencies, are the locus of both constitutional and statutory interpretation.”).

${ }^{27}$ George B. Shepherd, Fierce Compromise: The Administrative Procedure Act Emerges from New Deal Politics, 90 Nw. U. L. REv. 1557, 1581-82 (1996).

${ }^{28}$ See McNollgast, supra note 26, at 200 ("By granting authority to the (New Deal dominated) courts to interpret agency statutes, it prevents the new (Republican dominated) agency officials from altering policy by announcing a new interpretation of the statute.”).
} 
APA's constraints on executive power. McNollgast points out that the Democrats could see a Republican presidency on the horizon, but given the long-term Democratic control over judicial appointments, they viewed a relatively constraining APA, enforced on judicial review, as a method for consolidating New Deal policies against Republican attempts to adopt new policies. ${ }^{29}$ Thus, to McNollgast, non-deferential judicial review, such as independent judicial resolution of legal issues, was preferred by Democrats as a means of protecting New Deal policies from Republican reversal. ${ }^{30}$

Not surprisingly, the Executive Branch took a different view of the meaning of the APA at the time it was passed. The Attorney General's Manual on the Administrative Procedure Act stated simply that the judicial review provisions of the APA were meant to codify existing law. ${ }^{31}$ There are two problems with taking the Attorney General's view at face value. First, existing law was so unclear on many important issues, especially with regard to judicial review of legal interpretations, that codification would have meant that the APA provision had basically no discernible content. Second, the Attorney General seems to be stating the Executive Branch's case for a more lenient standard of review, not providing an objective viewpoint on congressional intent. ${ }^{32}$ Thus, although the Attorney General's Manual should be considered when trying to understand the APA, especially in those cases in which the Manual's interpretation is contrary to the Executive Branch's interests, it may be unreliable when it advances a pro-executive point of view.

In Chevron itself, the Court's departure from the statutory language is made most apparent when the Court paraphrases the APA's standard of review. The Court stated that when Congress explicitly leaves a statutory gap for the agency to fill, "legislative regulations are given controlling weight unless they are arbitrary, capricious, or manifestly contrary to the statute.” $^{33}$ The actual text of the APA states simply that the reviewing court should overturn agency action found to be "arbitrary, capricious, an

\footnotetext{
${ }^{29}$ This would support, for example, legal doctrines that make it difficult for agencies to change course. See Jack M. Beermann, Presidential Power in Transitions, 83 B.U. L. REV. 947, 984 (2003) (explaining how the Supreme Court's application of the arbitrary and capricious test makes it difficult for agencies to change their policies). Recently, the Court rejected the argument that the arbitrary, capricious test should apply in a less deferential manner when an agency reverses a prior policy. See, e.g., FCC v. Fox Television Stations, Inc., 129 S. Ct. 1800, 1810 (2009).

${ }^{30}$ McNollgast, supra note 26, at 200, 206.

${ }^{31}$ U.S. DEP'T OF JUSTICE, ATTORnEy GENERAL's MANUAL ON THE AdMinistrative Procedure ACt 93 (1947) [hereinafter ATtORNEY GenERAL's MANUAL]. With regard to APA section 10(e), codified as 5 U.S.C. § 706, the Attorney General's Manual states, "This restates the present law as to the scope of judicial review.” Id. at 108.

${ }^{32}$ George Shepherd offers strong arguments against the Supreme Court's tendency to defer to the Attorney General's Manual on questions involving interpretation of the APA. In general, Shepherd argues, the administration would have preferred weaker restraints on agencies than those contained in the APA, and the Attorney General's Manual portrays the APA in that light. See Shepherd, supra note 27 , at $1682-83$.

${ }^{33}$ Chevron U.S.A., Inc. v. NRDC, 467 U.S. 837, 844 (1984) (emphasis added).
} 
abuse of discretion, or otherwise not in accordance with law." 34 The addition of the word "manifestly" and the phrase "contrary to the statute" add deferential atmospherics, which might be appropriate with regard to a common law standard but seems beyond the proper judicial role in a statutory matter. The Court should have at least quoted the actual statutory language before construing it to allow deference to the agency's view. ${ }^{35}$

In the pre-APA period, although there was a long tradition of deference to agency interpretations, ${ }^{36}$ legal doctrine on the distribution of interpretive authority between courts and agencies was unclear and it often caused controversy. Some decisions indicated that courts should defer to agency interpretations, while others indicated the opposite. On the deference side, in the years before the passage of the APA, the Court gave "peculiar weight" to an agency practice that was supported by a "contemporaneous" agency interpretation of the statute, ${ }^{37}$ and stated that the judicial review function was to "determine that there has been . . . an application of the statute in a just and reasoned manner." ${ }^{38}$ Standing against deference, the Supreme Court had also declared that "[t]he interpretation of the meaning of statutes ... is exclusively a judicial function," ${ }^{39}$ and in the prominent Hearst decision, the Court appeared to reserve decisions on pure legal questions to itself, but then deferred in reviewing agency application of law to fact. ${ }^{40}$ The Court attempted to sum up the issue in Skidmore, in which it stated that the degree to which reviewing courts should defer to agency legal decisions "will depend upon the thoroughness evident in its consideration, the validity of its reasoning, its consistency with earlier and later pronouncements, and all those factors which give it power to persuade, if lacking power to control." ${ }^{11}$ To put it mildly, prior to the passage of the APA, there were competing traditions and unclear standards concerning whether agency legal decisions should receive deference on judicial review.

After the passage of the APA but before Chevron, at least some of the time, the federal courts seem to have understood that under the APA, legal interpretations were for independent judicial resolution. During this period, the issue of deference to agency legal decisions faded away

\footnotetext{
${ }^{34} 5$ U.S.C. § 706(1)(A) (2006) (emphasis added).

${ }^{35}$ The phrase "manifestly contrary to the statute" had not been used by the Supreme Court before Chevron. A similar phrase, "plainly contrary to the statute," was used the week before the Chevron decision. United States v. Morton, 467 U.S. 822, 834 (1984). For further discussion of Step Two, see infra note 121 and accompanying text.

${ }^{36}$ See Edwards' Lessee v. Darby, 25 U.S. (12 Wheat.) 206, 210 (1827) (emphasizing that interpretation of a law by persons who act under and carry its provisions into effect is entitled to "very great respect").

${ }^{37}$ Norwegian Nitrogen Prods. Co. v. United States, 288 U.S. 294, 315 (1933).

${ }^{38}$ Gray v. Powell, 314 U.S. 402, 411 (1941).

${ }^{39}$ United States v. Am. Trucking Ass'ns, 310 U.S. 534, 544 (1940).

${ }^{40}$ NLRB v. Hearst Publ'ns, 322 U.S. 111, 130-31 (1944).

${ }^{41}$ Skidmore v. Swift \& Co., 323 U.S. 134, 140 (1944).
} 
somewhat, although it did pop up on occasion. In some pre-Chevron APA cases, the Court simply declared the law without much attention to whether the agency's interpretation deserved deference. ${ }^{42}$ For example, in the Overton Park case, which contains the most prominent pre-Chevron discussion of judicial review under the APA, the Court interpreted the governing statute without even mentioning the views of the Secretary of Transportation, whose actions were being challenged. ${ }^{43}$ The best reading of that opinion is that the Court viewed interpretation of the statute as a matter for judicial determination without regard to the agency's views. ${ }^{44}$

The same is true in the Benzene Case, ${ }^{45}$ in which the Court construed the agency's authority under the OSH Act narrowly to avoid a potential nondelegation problem. The Court looked at the text and legislative history of the OSH Act and determined that the agency's interpretation of its authority under the Act was too broad. ${ }^{46}$ There is no hint of deference to the agency's views in the Court's opinion. Thus, perhaps because of the APA's language, in the period between the adoption of the APA and the Chevron decision, it appears that in many cases agency views on legal

${ }^{42}$ In O'Leary v. Brown-Pacific-Maxon, Inc., 340 U.S. 504, 507-08 (1951), the Court behaved as if the APA had not been passed, at least with regard to the question of deference to agency legal conclusions. In that case, the Court appears to have applied Hearst, distinguishing between "independent judicial ascertainment” of “"questions of law”" and questions involving the "experience of industry.” Id. This implicitly would involve deference à la Hearst, in which the Court stated:

[W] here the question is one of specific application of a broad statutory term in a proceeding in which the agency administering the statute must determine it initially, the reviewing court's function is limited. ... . [T]he Board's determination . . . is to be accepted if it has "warrant in the record" and a reasonable basis in law. Hearst, 322 U.S. at 131.

${ }^{43}$ Citizens to Pres. Overton Park, Inc. v. Volpe, 401 U.S. 402, 409-12 (1971).

${ }^{44}$ The Court discussed the statutory issue in Overton Park in two different parts of the opinion. It concluded its initial explication of the governing statute by saying, "This language is a plain and explicit bar to the use of federal funds for construction of highways through parks-only the most unusual situations are exempted.” Id. at 411. Later in the opinion, discussing the role of the court on judicial review, the Court stated:

The court is first required to decide whether the Secretary acted within the scope of his authority. . . . The reviewing court must consider whether the Secretary properly construed his authority to approve the use of parkland as limited to situations where there are no feasible alternative routes or where feasible alternative routes involve uniquely difficult problems.

Id. at 415-16. The only hint of deference in the Court's discussion of the statutory standard involves application of the judicially declared legal standard to the particular situation: "And the reviewing court must be able to find that the Secretary could have reasonably believed that in this case there are no feasible alternatives or that alternatives do involve unique problems.” Id. at 416. It is possible that the Court did not discuss deference because it found the statutory language "plain and explicit." It seems more likely, however, that deference simply did not seem relevant to review of the agency's understanding of the meaning of the statute.

${ }^{45}$ See Indus. Union Dep’t v. Am. Petroleum Inst., 448 U.S. 607, 641, 659 (1980) (holding that the Secretary of Labor exceeded authority under the OSH Act because the statute only required elimination of significant risks of harm, rather than requiring employers to provide an absolute risk-free workplace)

${ }^{46}$ See id. at 641-43, 646-52 (interpreting the text and legislative history of the statute to mean that the statute is concerned with the elimination of significant harm and not with the preservation of absolute safety as advocated by the Secretary of Labor). 
issues received little if any deference on judicial review. Because they were the most well known decisions, Chevron seemed to some to be a striking and abrupt change in settled practice. ${ }^{47}$

In other cases decided between the adoption of the APA and Chevron, however, the Court applied a deferential standard of review, upholding agency statutory interpretations if they were reasonable. ${ }^{48}$ For example, in language that foreshadows Chevron, the Court concluded that the Federal Election Commission's statutory interpretations should receive deference as follows:

Initially, we note that the Commission is precisely the type of agency to which deference should presumptively be afforded. Congress has vested the Commission with "primary and substantial responsibility for administering and enforcing the Act," providing the agency with "extensive rulemaking and adjudicative powers.” ...

The Commission's position on the question before us is clear. Since 1976, it consistently has adhered to its construction of [2 U.S.C.] $\S 441 \mathrm{a}(\mathrm{d})(3)$ as not forbidding intraparty agency agreements. . . . The Commission consistently has upheld the agency agreements; the fact that Commission Counsel has had the luxury of a number of sound arguments on which to base his opinions does not detract from the deference due the agency's interpretations ....

Hence, in determining whether the Commission's action was "contrary to law," the task for the Court of Appeals was not to interpret the statute as it thought best but rather the narrower inquiry into whether the Commission's construction was "sufficiently reasonable" to be accepted by a reviewing court. To satisfy this standard it is not necessary for a court to find that the agency's construction was the only reasonable one or even the reading the court would have reached if the question initially had arisen in a judicial proceeding. ${ }^{49}$

This language is close to but not quite the same as the apparent

${ }^{47}$ The lower courts seemed to understand the APA as assigning authority to decide legal questions to courts. In a Ninth Circuit opinion quoted by Duffy, the court stated, "In enacting the Administrative Procedure Act Congress did not merely express a mood that questions of law are for the courts rather than agencies to decide,--it so enacted with explicit phraseology.” Duffy, supra note 22, at 194 n.408 (quoting SEC v. Cogan, 201 F.2d 78, 86-87 (9th Cir. 1952)).

${ }^{48}$ See Fed. Election Comm. v. Democratic Senatorial Campaign Comm., 454 U.S. 27, 36-37, 39 (1981). Eskridge and Baer observe that "the Court was highly deferential to agency interpretations before Chevron.” Eskridge \& Baer, supra note 2, at 1120.

${ }^{49}$ Democratic Senatorial Campaign Comm., 454 U.S. at 37-39 (citations and footnotes omitted). 
meaning of the original Chevron standard as announced in the Chevron opinion itself. In the pre-Chevron APA cases that raised deference to agency statutory interpretation, although the Court stated the question as whether the agency's interpretation is reasonable, the Court engaged in a substantial inquiry to ensure that the agency's view was not inconsistent with congressional intent. ${ }^{50}$ In some cases, the analysis was similar to preAPA Skidmore deference, under which the degree of deference would vary based on numerous factors including the duration and consistency of the agency's interpretation, the process by which the interpretation was made, and the relevance of agency expertise to the issues. ${ }^{51}$ It was a much broader inquiry than Chevron's injunction to defer unless Congress had "directly addressed the precise question at issue." 52

What looked most different about Chevron was the bifurcation of review into Steps One and Two - the apparently narrow domain of Step One, in which the reviewing court would search for clear congressional intent, and the apparent virtual abdication of judicial authority if the case reached Step Two, which seemed likely in the vast majority of cases. ${ }^{53}$ In Chevron, it appeared that the Court was pulling back from any substantial review of interpretations in cases not resolved based on clear statutory meaning.

If Chevron is inconsistent with the APA, then this may provide an extremely strong basis for overruling it (or quietly abandoning it). ${ }^{54}$ In a recent decision declining to heighten judicial review under the arbitrary, capricious standard when an agency alters a policy, the Supreme Court relied on its Vermont Yankee principle that the APA is the final word on standards of judicial review. ${ }^{55}$ If so, and if the Court agrees that Chevron does not follow the APA, the Court should overrule it based on the

\footnotetext{
${ }^{50}$ See id. at 39-43 (examining the language, legislative history, and purposes of a statute to determine whether agency interpretation is reasonable); Indus. Union Dep't., 448 U.S. at 645-52 (same).

${ }^{51}$ Skidmore v. Swift \& Co., 323 U.S. 134, 140 (1944).

${ }^{52}$ Chevron U.S.A., Inc. v. NRDC, 467 U.S. 837, 843 (1984).

${ }^{53}$ See id. at 842-43.

${ }^{54}$ It may be argued that the Court has already abandoned Chevron to a certain extent, since it does not cite it in many of the cases in which it seems to apply. See discussion infra notes 200-06 and accompanying text. The problem with this argument is that in some cases the Court continues to cite Chevron as the authoritative standard and dissenters complain about the Court's faulty application of Chevron. There is no question, however, that the Court does not need to employ the Chevron framework even in cases in which deference to agency legal interpretations is an issue. See Michael C. Harper, Judicial Control of the National Labor Relations Board's Lawmaking in the Age of Chevron and Brand X, 89 B.U. L. REV. 189, 210 (2009) (noting that Brand X makes clear that serious arbitrary or capricious review should be applied when reviewing agency formulations of legal doctrine, even in instances of statutory construction where Chevron deference is claimed).

${ }^{55}$ See FCC v. Fox Television Stations, Inc., 129 S. Ct. 1800, 1810 (2009) (holding that APA review is not heightened when an agency revises its policy); Jack M. Beermann \& Gary Lawson, Reprocessing Vermont Yankee, 75 GEO. WASH. L. REV. 856, 871-74 (2007) (arguing that "the APA's procedural framework [is] a fundamental charter that courts should not unilaterally alter").
} 
Vermont Yankee principle that, absent unconstitutionality, courts have no authority to depart from the APA.

\section{No Adequate Theoretical Justification for Chevron}

When it was decided, some observers found Chevron to be a sharp break with accepted principles governing the division of interpretive authority between agencies and courts. ${ }^{56}$ When a court makes a sharp break with established practice, the burden is on the proponents to justify the change. To some, not only was Chevron lacking in sufficient justification for change, it was inconsistent with the traditional judicial authority to declare the law, embodied most famously in the statement in Marbury v. Madison that "[i]t is emphatically the province and duty of the judicial department to say what the law is." " Insofar as Chevron requires courts to accept agency interpretations that they find contrary to the best reading of the statute, at a minimum, Chevron undercuts judicial authority to declare the law.

In addition to what seemed to be a break with practice under the APA, some commentators found Chevron to be a violation of, or at least in tension with, principles of separation of powers. Very early on, Cynthia Farina argued that Chevron was inconsistent with the norms underlying the nondelegation doctrine and was inconsistent with the fundamental historical and philosophical principles that support the legitimacy of the exercise of legislative power by the government of the United States. ${ }^{58}$

${ }^{56}$ As noted, the Court itself might not have viewed Chevron as an exceptional decision. See Merrill, supra note 4, at 420 ("There is no evidence that Justice Stevens understood his handiwork in Chevron as announcing fundamental changes in the law of judicial review."); Molot, supra note 2, at $1259 \mathrm{n} .78$ ("It is true that the Justices at the time did not seem to 'realize[] the full implications of their landmark administrative law decision in . . Chevron.'” (quoting Robert V. Percival, Environmental Law in the Supreme Court: Highlights from the Marshall Papers, 23 ENVTL. L. REP. 10,606, 10,613 (1993))). There is no question, however, that soon after the decision, it became viewed as establishing a new, highly deferential, standard for reviewing agency statutory construction.

${ }^{57}$ Marbury v. Madison, 5 U.S. (1 Cranch) 137, 177 (1803); see CSX Transp. v. United States, 867 F.2d 1439, 1445 (D.C. Cir. 1989) (Edwards, J., dissenting) (observing that the Chevron rule appears to violate separation of powers principles and usurp the role of the courts to conduct statutory interpretation); Clark Byse, Judicial Review of Administrative Interpretation of Statutes: An Analysis of Chevron's Step Two, 2 ADMIN. L.J. 255, 261 (1988) (arguing that Chevron's reasoning that a statute's silence or ambiguity confers interpretive power on an agency is a violation of separation of powers principles); Linda D. Jellum, "Which Is To Be Master," the Judiciary or the Legislature? When Statutory Directives Violate Separation of Powers, 56 UCLA L. REV. 837, 897-98 (2009) (suggesting that the legislature intrudes into the judicial sphere when it enacts statutes directing courts on how to interpret statutes); Henry P. Monaghan, Marbury and the Administrative State, 83 CoLuM. L. Rev. 1, 2 (1983) (noting Marshall's conception of judicial autonomy in Marbury as suggestive of a condemnation of judicial deference to administrative construction of law).

${ }^{58}$ See Cynthia R. Farina, Statutory Interpretation and the Balance of Power in the Administrative State, 89 Colum. L. REV. 452, 478-81 (1989) (describing how the nondelegation doctrine prohibits the legislature from ceding lawmaking authority to another entity); see also Patrick M. Garry, Accommodating the Administrative State: The Interrelationship Between the Chevron and Nondelegation Doctrines, 38 ARIZ. ST. L.J. 921, 946-47 (2006) (detailing separation of powers critiques of Chevron). 
Clark Byse, a prominent administrative law scholar and co-author of one of the leading administrative law casebooks, also identified possible separation of powers problems with the Chevron doctrine relatively soon after the doctrine was created. ${ }^{59}$ Judge Harry Edwards picked up on Byse's suggestion, stating in an opinion soon after Chevron was decided that "Chevron's mandate is perplexing, because the rule of the case appears to violate separation of powers principles." ${ }^{60}$ Judge Edwards's analysis focused on Chevron's blanket assumption that every instance of statutory ambiguity gives rise to an inference that Congress delegated lawmaking power to an agency.

The point is not that Chevron actually violates separation of powers principles or that it was actually inconsistent with pre-existing doctrine. Rather, the point is that there was no strong normative support for Chevron at the time it was decided, and that the doctrine was in tension in multiple ways with the principles, doctrines and practices that had governed judicial review of agency legal conclusions up to that time. ${ }^{61}$ The lack of a solid basis for the doctrine virtually guaranteed that the doctrine would be applied inconsistently in the future as conflicting principles pulled decision makers with disparate views in different directions. Thus, it should have been no surprise that Chevron has turned out to be unstable and difficult to apply. ${ }^{62}$

The Supreme Court supplied two distinct normative bases for the Chevron doctrine: first, that Congress delegated the power to construe statutes to the agencies, and second, that agency decision making was preferable to judicial decision making on democracy and accountability grounds because agencies are politically responsive to the President, an elected official. Neither of these provides sufficient normative support for the Chevron doctrine. ${ }^{63}$

The problem with the first purported basis for the Chevron doctrine, that statutory ambiguity indicates congressional intent to delegate interpretive authority to the administering agency, is that in most circumstances it is false, a presumption that might be charitably called a

\footnotetext{
${ }^{59}$ See Byse, supra note 57, at 261.

${ }^{60}$ CSX Transp., 867 F.2d at 1445 (Edwards, J., dissenting).

${ }^{61}$ There are those who view Chevron as actually solving or at least ameliorating the separation of powers problems inherent in the delegation of policymaking power to administrative agencies. See Richard J. Pierce, Jr., Democratizing the Administrative State, 48 WM. \& MARY L. REV. 559, 562 (2006) (describing Chevron as "a major step toward legitimating and democratizing the administrative state").

${ }^{62}$ Clark Byse recognized early on that Chevron was proving to be more complicated to apply than its simple formulation suggested. See Byse, supra note 57, at 266-67.

${ }^{63}$ There has been a great deal of scholarly debate on the theoretical foundations of Chevron. Over time, as might be expected, the doctrine has become more accepted, although doubts about it continue to be raised. For a recent look at the foundations of the Chevron doctrine, see Evan J. Criddle, Chevron's Consensus, 88 B.U. L. REV. 1271, 1283-98 (2008). Agency expertise has become a third normative basis for Chevron deference, and is discussed infra, text accompanying notes 127-28.
} 
legal fiction. ${ }^{64}$ The Court cited no evidence for its conclusion that statutory ambiguity ordinarily indicates congressional intent to delegate interpretive authority to the agency administering the particular statute. A few years after Chevron was decided, Cass Sunstein stated that "[i]f there's any evidence of congressional views in the meantime, those views are very much in accord with the original spirit of the Administrative Procedure Act, that is, that administrative agency interpretations of law should not be deferred to." 65 Similarly, Byse found evidence of congressional delegation of interpretive authority to agencies lacking. ${ }^{66}$ Even Justice Scalia, one of the Court's strong proponents of Chevron deference, has stated that although the presumption regarding congressional intent is sensible in today's world, it "represents merely a fictional, presumed intent." 67 In

${ }^{64}$ See Lisa Schultz Bressman, Chevron’s Mistake, 58 DUKE L.J. 549, 562 (2009) (“[A] wide range of legal scholars have characterized the congressional delegation rationale for Chevron as a fiction.”). For a sample of commentators who agree with this characterization, see Einer Elhauge, Preference-Estimating Statutory Default Rules, 102 ColuM. L. REv. 2027, 2132 (2002) ("[E]ven adherents to [the Chevron] theory . . . acknowledge that the evidence of such enacting congressional intent is 'weak' and even 'fictional.'”); Jacob E. Gersen \& Adrian Vermeule, Chevron as a Voting Rule, 116 YALE L.J. 676, 689 (2007) (noting that Justices and commentators have recognized that the presumption of legislative intent underlying Chevron is a "fiction" and agreeing with this view); Daniel J. Gifford, The Emerging Outlines of a Revised Chevron Doctrine: Congressional Intent, Judicial Judgment, and Administrative Autonomy, 59 AdMIN. L. REV. 783, 799 (2007) (expressing skepticism over the delegation rationale for Chevron); Merrill \& Hickman, supra note 2, at 871-72 (noting that the presumption of legislative intent underlying Chevron deference "has been described by even [Chevron's] strongest defender [Justice Scalia] as 'fictional'”).

${ }^{65}$ Panel Discussion, Judicial Review of Administrative Action in a Conservative Era, 39 ADMIN. L. REV. 353, 368 (1987); see also Criddle, supra note 63, at 1286 n.70 (citing Duffy, supra note 22, at 194-95 for the proposition that the APA requires de novo review on questions of law).

${ }^{66}$ Byse noted:

[I]f Congress has delegated authority to determine what the statute means, the agency's interpretation, if reasonable, must be accepted by the courts. But the vital pre-condition for this conclusion is the court's determination that the agency has been delegated the power to define the statute. To reason, as Chevron does, that silence or ambiguity confers that kind of interpretative authority on the agency is unacceptable, for it assumes the very point in issue and thus "fails to distinguish between statutory ambiguities on the one hand and legislative delegations of lawinterpreting power to agencies on the other."

Byse, supra note 57, at 261 (quoting Cass R. Sunstein, Constitutionalism After the New Deal, 101 HARV. L. REV. 421, 466 (1987)).

${ }^{67}$ Antonin Scalia, Judicial Deference to Administrative Interpretation of Law, 1989 DuKE L.J. 511, 517 (1989). Although Justice Scalia is known as one of the Court's "strongest defender[s]" of Chevron, from the beginning he stated that he did not think that he would actually defer to agency interpretations as often as other judges because he "finds more often ... that the meaning of a statute is apparent from its text and from its relationship with other laws.” Gifford, supra note 64, at 799; Scalia, supra, at 521 (emphasis omitted). Justice Scalia seems to like Chevron for two reasons: first, because (at least until Mead) it appeared to create a comprehensive rule that would replace the pre-APA uncertainty over the issue, and second, because when a case was decided in Step Two, it would allow agency flexibility since agencies remain free to switch to another permissible interpretation. See id. at 517. Justice Scalia recognized that statutory ambiguity does not necessarily mean that Congress meant to delegate interpretive authority to an administering agency. In his article, he stated, "An ambiguity in a statute committed to agency implementation can be attributed to either of two congressional desires: (1) Congress intended a particular result, but was not clear about it; or (2) Congress had no particular intent on the subject, but meant to leave its resolution to the agency.” Id. at 516. 
short, except in those situations in which Congress explicitly delegates interpretive authority to an agency, ${ }^{68}$ or writes a provision that is so broad that it facially represents a delegation of policymaking authority to an agency, ${ }^{69}$ there is little reason to believe that ambiguity signals congressional intent to delegate interpretive authority to the administering agency and not to the reviewing court.

The conditions under which ambiguity arises support the conclusion that Congress does not intend to delegate interpretive power to agencies whenever a statute is ambiguous. Ambiguity arises in at least three situations: (1) when Congress has imperfectly expressed its intent; (2) when Congress has failed to anticipate all of the situations to which a statute might apply; and (3) when Congress has been unable or unwilling to come to a consensus on an issue and purposely left it unresolved in the statute. In the first and second type of case, in line with prevailing tradition and the language of the APA, at least before Chevron, Congress would have expected that any interpretive issue or gap would be resolved by a federal court performing judicial review. In fact, in the first type of case, since Congress intended to answer the issue and failed, Congress would not have anticipated that there would be any open interpretive issues to be resolved. In the third situation, assuming the statute is one that is administered by an agency, Congress would certainly have intended to delegate policymaking authority to the agency, subject to ordinary "arbitrary, capricious" review, but there is no evidence that Congress would have also intended to delegate power to interpret the statutory limits of that delegated policymaking power.

There are several factors that make delegation of interpretive authority to the administering agency unlikely. For one, it is inconsistent with the

\footnotetext{
${ }^{68}$ There are many federal statutes that explicitly delegate interpretive authority to an agency or official. For example, 5 U.S.C. § 3502(f)(3), which governs federal government force reductions, states, "An employee with critical knowledge and skills (as defined by the Secretary concerned) may not participate in a voluntary separation under paragraph (1)(A) if the Secretary concerned determines that such participation would impair the performance of the mission of the Department of Defense or the military department concerned.” 5 U.S.C. § 3502(f)(3) (2006) (emphasis added). This provision delegates to the secretaries of various departments the power to determine the meaning of the statutory phrase "critical knowledge and skills." Another example of delegation is a provision in 7 U.S.C. § 87b(d)(2)(D), a statute governing agricultural products. It provides, "Nothing in paragraph (1) shall be construed to prohibit ... the recombination of broken corn or broken kernels, as defined by the Secretary, with grain of the type from which the broken corn or broken kernels were derived[.]" 7 U.S.C. § 87b(d)(2)(D) (2006) (emphasis added). This provision delegates to the Secretary of Agriculture the authority to define "recombination," "broken corn or broken kernels," or both.

${ }^{69}$ For example, the Federal Communications Commission is charged with regulating the airwaves in the "public convenience, interest, or necessity." 47 U.S.C. $§ 303$ (2006). This is obviously a delegation to the Commission to make policy, and in a sense to define "public convenience, interest, or necessity." This is in sharp contrast with the myriad detailed provisions contained in the Telecommunications Act, which may be ambiguous but do not necessarily entail such broad delegations of interpretive authority. See, e.g., 47 U.S.C. § 259(a) (2006) (requiring the FCC to prescribe rules for infrastructure sharing).
} 
language of the APA and with the way the APA had been applied in the most prominent Supreme Court judicial review decisions prior to Chevron. ${ }^{70}$ There is no indication in any pre-Chevron understanding of the APA that Congress meant to disable courts from closely supervising agency compliance with law. Similarly, Congress does not usually view agencies as trusted partners, but rather views them as competing entities that need to be kept in line. ${ }^{71}$ The theoretical understanding of judicial review is that it is necessary to keep agencies from straying from the guidelines established by Congress and to provide a neutral forum for the resolution of disputes between the government and the governed. ${ }^{72}$ And insofar as agencies are likely to be cooperating with the President, there is no reason to believe that any time a statute is ambiguous Congress means to grant wide-ranging authority to the President. ${ }^{73}$

The second normative basis for Chevron-democracy and accountability-is more complicated but ultimately insufficient to justify the Chevron doctrine. The idea here is that because federal agencies are more politically accountable than the federal courts, statutory interpretation by agencies should be preferred over interpretation by the courts. ${ }^{74}$ For several reasons, this justification for Chevron is insufficient and in some senses fundamentally at odds with traditional conceptions of the judicial

\footnotetext{
${ }^{70}$ Even if Congress should now anticipate Chevron and understand that when it passes an incomplete or ambiguous statute to be administered by an agency it is delegating interpretive power to the agency, it makes no sense to apply Chevron's presumption of delegated interpretive power to statutes passed before Chevron was decided. See Caleb Nelson, Originalism and Interpretive Conventions, 70 U. CHI. L. REV. 519, 551-52 n.137 (2003).

${ }^{71}$ This is why Congress has designated some agencies as independent and located them outside of any Executive Branch department. The idea is not to shield them from politics but rather to allow for greater congressional, as opposed to presidential, influence. See FCC v. Fox Television Stations, Inc., 129 S. Ct. 1800, 1815-16 (2009) (noting that independent agencies are protected "not from politics but from the President”). Congress does not normally view Executive Branch agencies as allies in the pursuit of congressional policies. See Jack M. Beermann, Congressional Administration, 43 SAN DiEgO L. Rev. 61, 122-23, 127 (2006) (discussing the power struggle between the executive and legislative branches with regard to agency action).

72 "Broad delegations of power to regulatory agencies have been allowed largely on the assumption that courts would be available to ensure agency fidelity to whatever statutory directives have been issued.” Cass R. Sunstein, Interpreting Statutes in the Regulatory State, 103 HARV. L. REV. 405, 446 (1989).

${ }^{73}$ Evan Criddle recently argued that the Mead decision increases Chevron's reliance on congressional delegation of authority to agencies, and that it is unfortunate because the purported delegation is often not real. Criddle, supra note 63, at 1274-75.

${ }^{74}$ Richard Pierce has been a strong supporter of Chevron deference based on reasons of democracy. See Pierce, supra note 61, at 562. He therefore criticizes limitations on the applicability of Chevron as inhibiting Chevron's democracy-enhancing potential. See id. at 584-85 (discussing how a narrower scope of Chevron deference makes it difficult for a new President's policy to receive judicial approval). Pierce has also supported Chevron as allowing agencies to make policy decisions free from judicial decisions that impose judges' own preferences. See Richard J. Pierce, Jr., Chevron and Its Aftermath: Judicial Review of Agency Interpretations of Statutory Provisions, 41 VAND. L. REV. 301, 313 (1988). Pierce also argues that if the strongest, most deferential form of Chevron were applied, it would simplify the process of judicial review and therefore create more agreement among judges engaged in such review. See id. at 311.
} 
role in administrative law.

The first problem with the democracy and accountability justification for Chevron is that the accountability advantage for administrative agencies, especially independent agencies, is not very clear. The Chevron Court viewed administrative agencies as more accountable than federal courts. The Court acknowledged that "[administrative] agencies are not directly accountable to the people." ${ }^{, 5}$ As the Court explained, the accountability advantage is through the President:

While agencies are not directly accountable to the people, the Chief Executive is, and it is entirely appropriate for this political branch of the Government to make such policy choices-resolving the competing interests which Congress itself either inadvertently did not resolve, or intentionally left to be resolved by the agency charged with the administration of the statute in light of everyday realities. ${ }^{76}$

This discussion assumes that agency statutory interpretation is conducted under supervision of the President or at least political appointees of the President.

There has been a great deal of attention paid in recent years to the degree of presidential involvement in agency decision making. There is no question that there is more centralized control than there used to be, and that this centralized control has become a visible, institutionalized aspect of administrative law. ${ }^{77}$ This does not necessarily mean, however, that agency statutory interpretation is preferable to judicial interpretation on accountability grounds. Rather, it depends on what the courts are actually doing when they conduct judicial review and on the actual degree of accountability for agency statutory decisions.

This aspect of the Chevron Court's analysis depends on a very negative view of what judges do when construing ambiguous statutes. The Court raised the specter of decisions made "on the basis of the judges' personal policy preferences." ${ }^{, 7}$ The Court does not entertain the possibility that federal judges are at least trying to be faithful agents of the legislature when they interpret. The choice between life-tenured judges' personal preferences and a possibly somewhat accountable agency is easy. In the real world, however, the choice is nowhere near that clear.

Justice Scalia's proclamation that he is more likely than other judges to find statutes clear and unambiguous, which has led him to reject agency

\footnotetext{
${ }^{75}$ Chevron U.S.A., Inc. v. NRDC, 467 U.S. 837, 865 (1984).

${ }^{76}$ Id. at 865-66; see also infra text accompanying notes 93-104 (discussing implications of the Court's view that most issues of statutory interpretation are policy choices).

${ }^{77}$ For the classic work in this area, see Elena Kagan, Presidential Administration, 114 HARV. L. REV. 2245 (2001) (describing and analyzing presidential involvement in the administrative process).

${ }^{78}$ Chevron, 467 U.S. at 865.
} 
views more often than might be expected from such a strong advocate of Chevron deference, should give pause to basing Chevron deference on the view that judges impose their own personal policy preferences when they construe statutes. ${ }^{79}$ Rather, like Justice Scalia, judges reading statutes may in many instances be attempting, in good faith, to apply the statute in the way that Congress would have wanted them to. Justice Scalia's recent opinion for the Court in a case involving the meaning of "visitorial powers" in a statute granting federal regulators exclusive "visitorial powers" over national banks is a model of careful analysis of the meaning of ambiguous statutory language. ${ }^{80}$ The federal Comptroller of the Currency had promulgated a regulation reading the term expansively to preclude any state regulation of national banks, preempting even judicial enforcement of state law against national banks. ${ }^{81}$ Although the agency's litigation position was more moderate, Justice Scalia's opinion for the Court persuasively explains why Congress could not have intended to preclude enforcement of state law through judicial action. This decision is but one of many possible illustrations of how the potentially greater political accountability of agencies does not provide a sufficient theoretical basis for abandoning the traditional view that judicial review keeps agencies in line with congressional intent. ${ }^{82}$

If federal judges, who are by design the least accountable officials in the federal government, are imposing their own personal policy views, then of course non-deferential judicial review would reduce democratic accountability. However, when federal judges attempt, in good faith, to discern the intent of Congress, then the choice may be better understood as between an agency advancing its own or the President's policy agenda and a reviewing court trying to force the agency to stick to the agenda that Congress established for it. ${ }^{83}$ The traditional view of judicial review is that

\footnotetext{
${ }^{79}$ In a recent decision, Justice Scalia chided Justice Stevens for arguing in dissent that a statute's plain meaning was "in the eye of the beholder" within weeks of arguing, in another dissent, that the meaning of the statute in that case was plain. Tellabs, Inc. v. Makor Issues \& Rights, Ltd., 551 U.S. 308, 332 (2007) (Scalia, J., concurring in judgment) (internal citations omitted) (referencing Rockwell Int'l Corp. v. United States, 549 U.S. 457, 479 (2007) (Stevens, J., dissenting)).

${ }^{80}$ Cuomo v. Clearing House Ass'n, 129 S. Ct. 2710, 2715-19 (2009).

${ }^{81}$ See id. at 2714-15.

${ }^{82}$ This decision illustrates the potential inconsistency between Justice Scalia's propensity for finding clear statutory meaning and competing understandings of the Chevron framework. In dissent for himself and three others, Justice Thomas argued that since Justice Scalia's opinion acknowledged that the phrase "visitorial powers" is ambiguous, it should have applied Chevron and approved the agency's interpretation in Step Two: “The statutory term 'visitorial powers' is susceptible to more than one meaning, and the agency's construction is reasonable.” Id. at 2723 (Thomas, J., concurring in part and dissenting in part).

${ }^{83}$ It is, of course, much more complicated than this simple statement. As Linda Jellum illustrates, Justice Scalia's plain meaning version of Chevron can be understood as rejecting the search for “"unenacted legislative intent." ' Linda Jellum, Chevron's Demise: A Survey of Chevron from Infancy to Senescence, 59 Admin. L. REv. 725, 751 (2007) (quoting INS v. Cardozo-Fonseca, 480 U.S. 421, 452-53 (1987) (Scalia, J., concurring)). Justice Scalia apparently believes that when courts stray
} 
courts prevent agencies from straying too far from congressional intent. ${ }^{84}$ As Michael Herz has succinctly stated:

[W]hile, as Chevron emphasizes, agencies have an edge on courts in accountability, they have no such edge on Congress. To the contrary, giving agencies too free a hand trenches on congressional authority, thereby reducing accountability. To the extent Congress has in fact decided something, Chevron's own political theory requires the courts to ensure that agencies act consistently with that decision. ${ }^{85}$

Democracy is not only a function of whether the particular officials making specific decisions are accountable either themselves or through another elected official such as the President. The entire decisionmaking process needs to be examined to determine whether there has been maximum democratic control of the process. If an administrative agency makes a decision that seems contrary to ambiguously expressed congressional intent, and a federal judge, after examining the statutory text and structure, the statute's relationship with other statutes, the legislative history and the overall purposes Congress sought to achieve in the statute ${ }^{86}$ finds that the agency's decision was inconsistent with probable congressional intent, then the judge's decision supports the basic democratic and constitutional norm that Congress is the preferred institution for making decisions of social policy. ${ }^{87}$ This is even more true if Congress, by statute, has assigned this role to the courts, because then limiting review would be contrary to Congress's judgment that judicial

beyond statutory language, especially when that language is unambiguous under accepted legal standards, they are more likely to err with regard to legislative intent than when they stick to textual analysis. See Cardozo-Fonseca, 480 U.S. at 452-53 (Scalia, J., concurring in the judgment) (arguing against use of legislative history when statutory language is clear).

${ }^{84}$ See Sanford N. Caust-Ellenbogen, Blank Checks: Restoring the Balance of Powers in the PostChevron Era, 32 B.C. L. REV. 757, 793-94 (1991) ("In effect, judicial review preserves the principle of legislative supremacy.”); William M. Landes \& Richard A. Posner, The Independent Judiciary in an Interest-Group Perspective, 18 J.L. \& ECON. 875, 882 (1975). As I have argued elsewhere, in Massachusetts v. EPA, the Supreme Court moved toward favoring aggressive judicial review as a means of preventing federal agencies from advancing the administration's policies to the exclusion of Congress's legislatively expressed preferences. This may be reflective of an evolution toward a greater recognition of congressional primacy in administrative law. See Jack M. Beermann, The Turn Toward Congress in Administrative Law, 89 B.U. L. REv. 727, 732, 742-43 (2009); see also Massachusetts v. EPA, 549 U.S. 497, 533 (2007) ("To the extent that this constrains agency discretion to pursue other priorities of the Administrator or the President, this is the congressional design.”).

${ }^{85}$ Michael Herz, Deference Running Riot: Separating Interpretation and Lawmaking Under Chevron, 6 ADMIN. L.J. AM. U. 187, 189-90 (1992) (footnotes omitted).

${ }^{86}$ Reliance on an overall purpose is dangerous for the reasons explained by Justice Thomas in his concurring opinion in Wyeth v. Levine, 129 S. Ct. 1187, 1217 (2009). Just how far Congress was willing to go with any particular purpose is best determined by looking at the statutory text. Nonetheless, awareness of the purpose of a statute can help to understand the words, as long as it is done cautiously.

${ }^{87}$ See Indus. Union Dept. v. Petroleum Inst., 448 U.S. 607, 674-76 (1980) (Rehnquist, J., concurring in the judgment). 
review enhances democratic (i.e., congressional) control over agencies.

The implications of Chevron's view of the judicial process for the legal system are staggering, given the wide range of judicial activism in our current system. $^{88}$ I do not necessarily disagree with it, and I have advocated for judicial modesty in light of this and related problems with judicial activism, ${ }^{89}$ but it is no basis for the Chevron doctrine for several related reasons. For one, it seems disingenuous to invoke the lack of judicial accountability in this context while feeling free to run roughshod over the preferences of other branches of government in so many other contexts. Another problem with this reasoning is that it no longer accurately reflects the Chevron doctrine itself. The Court decides so many Chevron cases in Step One that it is more accurate to characterize Chevron in many cases as a doctrine of judicial supremacy in administrative law. ${ }^{90}$ Finally, this reasoning on its own terms is unpersuasive because the accountability of administrative agencies through the President remains exceedingly weak even in light of the increased centralization of the management of the administrative state.

The accountability of administrative agencies through the President is weakest with regard to independent agencies such as the Federal Communications Commission, the Federal Trade Commission, and the National Labor Relations Board. The connection of these agencies to the President is tenuous. Their members are appointed by the President, but they are shielded from direct presidential control by removal restrictions, bipartisanship requirements, and lengthy staggered terms that leave appointees of the President's predecessor in office for at least a substantial period in a new President's first term. Rules issued by these agencies are not subject to the rigorous centralized review applied to agencies within traditional government departments, and often these agencies are more receptive to pressure from members of Congress than from the President or other Executive Branch officials.

Even for agencies firmly within the Executive Branch, accountability through the President is greater, but not necessarily very strong. Centralized review, presidential appointment of department heads and agency heads, and power to discharge uncooperative officials all combine to place Executive Branch agencies under greater presidential control than the independent agencies. Agencies within the Executive Branch, however, are still subject to intense political pressure from many fronts, including, most notably, Congress. When agencies succumb to congressional pressure, this may not be democracy-enhancing because the

${ }^{88}$ See Jack M. Beermann, The Supreme Common Law Court of the United States, 18 B.U. PUB. INT. L.J. 119, 124-28 (2008).

${ }^{89}$ See id. at 121-30.

${ }^{90}$ See Beermann, Turn Toward Congress, supra note 84, at 749. 
members of Congress involved in the particular matter may represent narrow interests, either their own or of their particular constituents, rather than the interests of Congress as a whole. Congressional oversight can increase or decrease democratic accountability, depending on the particular context. $^{91}$

Even if the only outside influence on agency decision making came from the President, it is not clear whether this is desirable from a democratic standpoint. Agencies deal with scores of issues that may never be salient in a presidential election, when symbolism and overall leadership qualities may be much more important than the President's views on any particular issue likely to come before an administrative agency. The electorate has a small set of choices for President, and the President's views on most regulatory matters are less likely to reflect the electorate's preferences than the policies embodied in statutes passed by a majority of both houses of Congress. ${ }^{92}$ Given the miniscule degree of agency accountability through the President, the relative accountability basis for Chevron depends on a strong rejection of the legitimacy of judicial statutory interpretation. One wonders whether Chevron's supporters are willing to apply this distrust of judges across the board to all the ways in which federal courts interfere with the expressed preferences of the other branches of federal and state governments.

There is an additional factor that has not been well-integrated into the discussion of the legitimacy of Chevron: the fact that the Court justified Chevron deference in part based on the fact that statutory interpretation often involves policy considerations. ${ }^{93}$ To use Chevron itself as the example, the question for the agency was not only whether the bubble concept was consistent with the term "stationary source," but also whether using the bubble concept was a sensible method of regulating air pollution. The Chevron Court stated that "the decision involves reconciling conflicting policies." 94 The opinion then speculates on why the policy issue was not resolved by Congress, and offers as one possible answer that "[p]erhaps [Congress] consciously desired the Administrator to strike the balance at this level, thinking that those with great expertise and charged with responsibility for administering the provision would be in a better

\footnotetext{
${ }^{91}$ See Beermann, Congressional Administration, supra note 71, at 122-23.

${ }^{92}$ This analysis assumes that, but for Chevron deference, the agency's action would be found by a court to be contrary to Congress's intent as expressed in the (ambiguous) language of the relevant statute. Of course, if reviewing courts are advancing the personal preferences of the judges, then the agency's action should be upheld. If, however, judges are doing their best to put their own preferences aside and decide cases in line with what they think Congress would want, then the question becomes much more complicated. It would then boil down to whether agency accountability and the possibility that judges are not able to set aside their preferences are sufficient to outweigh the possibility that the reviewing court's statutory interpretation accurately reflects congressional intent.

${ }^{93}$ Chevron U.S.A., Inc. v. NRDC, 467 U.S. 837, 844 (1984).

${ }^{94}$ Id. at 865.
} 
position to do so." ${ }^{95}$ The Court goes on to support its preference for agency decision making based on expertise and accountability. ${ }^{96}$

The involvement of policy may help explain why Chevron jurisprudence is such a mess. Linguistically, the doctrine is presented, constructed, and elaborated as a method of review for questions of statutory interpretation focusing on statutory meaning, but in many of the cases the real question is whether the agency has employed its delegated power wisely, and one reason offered for deference is agency policy expertise. The Chevron framework is not suited to review of policy decisions, where the statutory arbitrary, capricious framework governs. It is as if the Court handed out tape measures and instructed people to weigh objects with them. ${ }^{97}$

Chevron presented two distinct questions, one interpretive and one policy. The interpretive question was whether the statutory term "stationary source" required that each smokestack or vent be treated as a separate source of air pollutants. ${ }^{98}$ The policy question was, assuming statutory authority, whether it was arbitrary or capricious for the agency to treat the aggregation of smokestacks and vents at a factory as a single stationary source under the statute. ${ }^{99}$ Policy decisions, such as whether automobiles should be required to be equipped with passive restraints, or what gas mileage a fleet of automobiles should be required to achieve, are typically reviewed under the arbitrary, capricious standard and do not fit well within the Chevron framework. Because many, and perhaps most, policy questions can be connected to an issue of statutory meaning, it cannot be that the Court intended virtually complete judicial renunciation of policy review so long as policy concerns are connected to a question of statutory meaning. ${ }^{100}$

The more conventional view, based on the language of the Chevron opinion, is that Chevron is largely about "agency interpretation of statutes." 101 There are those, however, who view Chevron as primarily

\footnotetext{
${ }^{95} I d$.

${ }^{96} I d$. at $865-66$.

${ }^{97}$ Cf. Bendix Autolite Corp. v. Midwesco Enter., Inc., 486 U.S. 888, 897 (1988) (Scalia, J., concurring) ("It is more like judging whether a particular line is longer than a particular rock is heavy.").

${ }^{98}$ Chevron, 467 U.S. at 840.

${ }^{99}$ This separation is not necessarily completely clean because whether something is arbitrary or capricious may, in some circumstances, be measured by whether it comports with the statutory standards. See infra note 110 and accompanying text.

${ }^{100}$ It would be odd to think that the Court would decide the Airbags Case, which announced a relatively stringent standard of review under the arbitrary, capricious standard, and in the very next year establish, with Chevron, a nearly toothless standard for reviewing policy decisions that are connected to issues of statutory meaning. See Motor Vehicle Mfrs. Ass'n of the U.S., Inc. v. State Farm Mut. Auto. Ins. Co. (Airbags Case), 463 U.S. 29, 41-42 (1983).

${ }^{101}$ Thomas W. Merrill, The Story of Chevron: The Making of an Accidental Landmark, in Administrative LAW StORIES 398, 401 (Peter L. Strauss ed., 2006).
} 
about policy, not about statutory interpretation. For example, Michael Herz stated in an article published not long after Chevron was decided that "[w]hat 'binds' a court, then, under both the traditional interpretive/legislative rule distinction and under Chevron, is not agency interpretation but agency legislation - the adoption of a particular policy within the boundaries established by the statute." ${ }^{102}$ Herz's conclusion depends in part on the Court's explicit exception from Chevron deference for "pure question[s] of statutory construction." 103 Writing more recently, Michael Harper also views Chevron as largely about review of agency policy decisions, but he adds that "formulations of legal doctrine should include the serious arbitrary or capricious review delineated in decisions like State Farm." 104

It is difficult to figure out what to make of the distinctions among agency law making, policy making, and pure questions of statutory construction under Chevron. It is doubtful that the Court intended Chevron Step Two's incredibly deferential permissible construction or reasonable interpretation standard to be appropriate for reviewing policy decisions. Because the arbitrary, capricious standard is the normal APA standard of review for agency policy decisions, if the real issue is not about meaning, but rather is about the wisdom of an agency policy, then the Chevron framework is an awkward fit.

To attempt, as some have done, to integrate Chevron and review of policy decisions creates some of its own logical problems. Early on in the life of the Chevron doctrine, Judge Harry Edwards argued in favor of a third step in Chevron cases. ${ }^{105}$ Judge Edwards reasoned that in cases in which the agency's interpretation is upheld in Steps One and Two, the reviewing court should consider, in a third step, whether the agency's interpretation is arbitrary and capricious under APA section 706(2)(B). ${ }^{106}$ This makes sense in light of the Chevron opinion's invocation of agency expertise to resolve policy conflicts as a reason for deference. However, insofar as Chevron and its progeny purport to be about agency statutory interpretation (although perhaps not about "pure questions of statutory construction"), it is difficult to imagine that a reasonable or permissible construction of a statute could be arbitrary and capricious as a matter of policy. If the construction of the statute is consistent with Congress's

102 Herz, supra note 85, at 199.

${ }^{103}$ Id. at 222-25.

${ }^{104}$ Harper, supra note 54, at 210.

105 See Int'l Bhd. of Elec. Workers v. ICC, 862 F.2d 330, 338 (D.C. Cir. 1988). The various arguments over how many steps are or should be in the Chevron process are discussed below.

${ }^{106}$ See id. at 338 ("Even if the ICC is not without authority under the ICA to review arbitration awards, a question remains whether the agency's announced decision to do so was 'arbitrary or capricious.' . . . [W] must consider whether the agency abused its discretion in exercising the quasilegislative authority delegated to it by Congress.” (citation omitted)). 
intent, then the agency has by definition considered the factors Congress intended it to consider and made a decision within the policy boundaries established by Congress. In this light, the two-step process makes no sense except perhaps as a different way of stating the arbitrary, capricious standard in the statutory interpretation context. ${ }^{107}$ If that is what the Court intends, the Court could simply apply a highly deferential version of the arbitrary, capricious standard as it does in other contexts. ${ }^{108}$

If the Supreme Court were to choose to make only one clarification to the Chevron doctrine, it should clarify the interaction between Chevron and judicial review of agency policy decisions. If Chevron deference is really about deference to agency policy decisions, then it seems to be running on a parallel track to review under the arbitrary, capricious standard with no reasoning as to which is the proper track in any particular case. If it is not about deference to policy decisions, then the Court needs to explain the proper standard of review for policy decisions that are connected with questions of statutory meaning.

Justice Scalia has offered an additional justification for Chevronagency flexibility. ${ }^{109}$ In his view, a great virtue of the Chevron doctrine is that it allows agencies to change their statutory interpretations upheld in Chevron Step Two as long as subsequent interpretations are also reasonable or permissible. ${ }^{110}$ The Brand $X^{111}$ decision made clear what had long been understood about Chevron, that when a reviewing court

${ }^{107}$ See Ronald M. Levin, The Anatomy of Chevron: Step Two Reconsidered, 72 CHI.-KENT L. REv. 1253, 1276 (1997) (suggesting that Chevron Step Two is simply arbitrary, capricious review).

${ }^{108}$ The Court has prescribed a highly deferential application of the arbitrary, capricious standard for reviewing agency denials of petitions to bring enforcement action and agency denials of petitions to engage in rulemaking. See Massachusetts v. EPA, 549 U.S. 497, 527-28 (2007) ("Refusals to promulgate rules are thus susceptible to judicial review, though such review is 'extremely limited' and 'highly deferential.'”); Dunlop v. Bachowski, 421 U.S. 560, 568 (1975) (holding that a narrowly limited scope of judicial review should apply to reviewable agency refusals to initiate enforcement proceedings). I do not necessarily agree that the standard of review of policy decisions made in the course of statutory interpretation should be more deferential than the usual standard. The Court has, however, adjusted the strength of the arbitrary, capricious standard in other contexts, and there is no reason why it could not do so here as well if it was concerned that ordinary arbitrary, capricious review would be too stringent.

${ }^{109}$ United States v. Mead Corp., 533 U.S. 218, 244 (2001) (Scalia, J., dissenting) ("Is it likely—or indeed even plausible - that Congress meant, when such an agency chooses rulemaking, to accord the administrators of that agency, and their successors, the flexibility of interpreting the ambiguous statute now one way, and later another ... ??").

${ }^{110}$ See id. at 247 (Scalia, J., dissenting) (asserting that where Chevron applies, agencies are free to replace previous statutory interpretations as part of their continuing discretion).

${ }^{111}$ Nat'l Cable \& Telecomms. Ass'n v. Brand X Internet Servs., 545 U.S. 967 (2005). Justice Scalia dissented in Brand $X$ because he viewed the Commission's interpretation of the provisions at issue in the case as unlawful. Id. at 1005 (Scalia, J., dissenting). He also expressed concern over the application of the principles of Mead (Chevron Step Zero). Id. at 1014-15 (Scalia, J., dissenting). He did not, however, disagree with the basic premise that agencies are free to adopt a new permissible construction of a statute if an agency's prior construction had been approved on judicial review. Id. at 1016 n.11 (Scalia, J., dissenting). He did, however, disagree with applying that premise when the court's initial decision had not been made under Chevron. Id. at 1019 (Scalia, J., dissenting). 
approves an agency's statutory interpretation as permissible, the agency remains free to adopt a different permissible interpretation, unless the first decision was based on clear congressional intent under Chevron Step One. ${ }^{112}$ Without deference to statutory interpretation, once an agency's interpretation is upheld on judicial review, it can be altered only by an amendment to the statute or by convincing the reviewing court to overrule its prior decision. Both options are likely to be difficult to accomplish. Getting Congress to pass any statute is very difficult, and statutory precedents are thought to have the greatest force in conventional understandings of the case law system. ${ }^{113}$ Flexibility in statutory interpretation would mirror flexibility in non-interpretive policy mattersas the Court has recently stated, changes in agency policy are not subject to heightened review under the arbitrary, capricious test. ${ }^{114}$

Applying Brand $X$ can be complicated because it may not always be easy or even possible to discern whether an initial decision was based on clear statutory meaning or deference to an agency's views. This is especially true for decisions that pre-date Chevron or the APA, but even the post-Chevron decisions are sometimes confusing as to what step the Court is applying when it approves an agency interpretation. ${ }^{115}$

Adding to the difficulties with the Chevron framework, the Brand $X$ decision has proven easy to circumvent. In the Cuomo decision, Justice Scalia's opinion for the Court cited several prior Supreme Court decisions, dating back to 1819, for the proposition that the phrase "visitorial power" did not include judicial enforcement of state law. ${ }^{116}$ The dissent accused the Court of violating Brand $X$-since the Court had determined that the statute was ambiguous, prior judicial understandings were not relevant under Brand $X$ because those cases had not definitively determined the meaning of the statute at issue. ${ }^{117}$ The only question should have been

${ }^{112}$ The application of this aspect of Brand $X$ has also proven controversial. See infra notes 11517 and accompanying text.

${ }^{113}$ EDWARD H. LEVI, AN InTRODUCTION TO LEgAL REASONING 31-33 (1949).

${ }^{114}$ FCC v. Fox Television Stations, Inc., 129 S. Ct. 1800, 1810-11 (2009).

${ }^{115}$ The Court makes this determination difficult by sometimes jumping to Chevron Step Two without first announcing that the statute is ambiguous. See, e.g., Entergy Corp. v. Riverkeeper, Inc., 129 S. Ct. 1498, 1505 (2009) (discussing whether an agency's interpretation is reasonable without first addressing whether the statute is ambiguous); Babbitt v. Sweet Home Chapter of Cmtys. for a Great Or., 515 U.S. 687, 696-703 (1995) (same). In Zuni Public School District No. 89 v. Department of Education, 550 U.S. 81, 90-99 (2007), in an opinion by Justice Breyer, the Court first determined that the agency's interpretation was reasonable and then decided that the statute was ambiguous. The Court switched the order of analysis because the language of the statute pointed strongly against the agency's interpretation. Id. at 89. In his dissent, Justice Scalia found the agency's interpretation contrary to the statute's plain language. Id. at 109-10 (Scalia, J., dissenting).

${ }^{116}$ Cuomo v. Clearing House Ass'n, 129 S. Ct. 2710, 2716-17 (2009) (citing Watters v. Wachovia Bank, N.A., 550 U.S. 1, 8 (2007); First Nat'l Bank in St. Louis v. Missouri, 263 U.S. 640, 660 (1924); Guthrie v. Harkness, 199 U.S. 148, 157 (1905); and Trs. of Dartmouth Coll. v. Woodward, 17 U.S. (4 Wheat.) 518, 676 (1819)).

${ }^{117}$ Cuomo, 129 S. Ct. at 2728-29 (Thomas, J., dissenting). 
whether the new interpretation was permissible under Chevron Step Two. ${ }^{118}$ Justice Scalia's response was that he was using the old cases as evidence of the meaning of the statutory phrase, not as binding authority. ${ }^{119}$ Justice Scalia is technically correct, but on reflection, his distinction is difficult to sustain, given that the Court is always free to overrule its prior decisions. In truth, all precedent is evidence of what the law is, not a body of rules that are binding at the Supreme Court level.

In any case, flexibility may be a virtue of Chevron but it does not provide a theoretical basis for the doctrine. There are many possible practices regarding agency statutory interpretation with varying degrees of flexibility. The Court could retain flexibility outside of the Chevron context by identifying situations in which it finds that an agency's interpretation is within the range of reasonable or permissible constructions. $^{120}$ Flexibility does not overcome objections based on statutory text, principles of statutory interpretation, and administrative law traditions. In sum, Chevron's departure from the text of the APA and traditional understandings of the distribution of power between agencies and courts has not been adequately justified.

\section{B. Problems Applying Chevron}

The next five enumerated reasons for overruling Chevron fall into the "problems in application" category. Several of these are connected to the first category, intrinsic problems, and the third category, costs and benefits of applying Chevron, particularly those involving uncertainty, which leads to increased litigation costs. These five reasons for overruling Chevron are as follows: (1) the Chevron opinion was poorly constructed and unclear on basic issues; (2) a short time after establishing the Chevron doctrine, the Court created a new version of Step One which threw the doctrine into disarray and spawned several competing versions of Step One, leading to conflicting lines of cases; (3) Chevron did not have the desired effect of increasing deference to agencies but instead left reviewing courts free to

\footnotetext{
${ }^{118} I d$. at 2730-31 (Thomas, J., dissenting).

${ }^{119} \mathrm{Id}$. at 2717 n.2.

${ }^{120}$ Justice Scalia argued in dissent in Brand $X$ that this sort of flexibility is not possible outside the Chevron framework. Nat'l Cable \& Telecomms. Ass'n v. Brand X Internet Servs., 545 U.S. 967, 1019 (2005) (Scalia, J., dissenting). Justice Scalia characterized Neal as "reject[ing] the notion that any form of deference could cause the Court to revisit a prior statutory-construction holding." Id. at 1016 n.11 (citing Neal v. United States, 516 U.S. 284, 295 (1996)). But Neal is not dispositive because in that case, the Court's initial interpretation was on direct review in a criminal case without the benefit of an administrative construction. Neal, 516 U.S. at 288. Nothing in Neal would preclude the Court from allowing agencies to reinterpret statutes when the initial judicial determination was made on deferential judicial review. Justice Scalia may be correct that an agency should not be allowed to adopt an interpretation that had previously been rejected on judicial review, but he is incorrect insofar as his argument holds that the Neal reasoning precludes an agency from adopting an interpretation different from one that had been previously approved but that had never been previously rejected itself.
} 
reach any desired result; (4) the Supreme Court does not even cite Chevron in a high proportion of the cases in which it arguably applies, which means that something is wrong with the doctrine; and (5) Chevron created uncertainty over when it applies, which made it necessary for the Court to construct a complicated and unclear doctrine to determine Chevron's domain, known as Chevron Step Zero.

\section{Chevron Was Poorly Constructed and Unclear on Basic Issues}

The Chevron opinion itself, and the doctrine that has grown out of it, is a failure because it does not provide clear answers to the issues it raised and thus led to great uncertainty and diversity of understanding and application. Many of these problems with Chevron have been adverted to above and are reviewed here only briefly.

The first problem discussed in this subsection is the mess the Court created with Chevron Step Two. As previously discussed, there is a lack of factual basis for the Court's assertion that whenever Congress is unclear, it intends to delegate interpretive power to the administering agency. ${ }^{121}$ This subsection discusses another problem, the lack of clarity of the Court's explication and application of Chevron Step Two. In constructing Step Two of Chevron, under which reviewing courts defer to agency interpretations of ambiguous statutes, the Court distinguished between explicit and implicit delegations of interpretive power to agencies. The Court first stated that whenever Congress has not directly spoken to the precise question at issue, the statute is therefore silent or ambiguous on "the specific issue, [and] the question for the court is whether the agency's answer is based on a permissible construction of the statute." 122 Then the Court went on to distinguish between explicit gaps, where the agency interpretation is reviewed under the "arbitrary, capricious, or manifestly contrary to the statute" standard and implicit gaps, which are reviewed under the "reasonable interpretation" standard. ${ }^{123}$

The origins of the Chevron Step Two dichotomy turn out to be very interesting. There was, before Chevron, a tradition in administrative law to give less deference to agency interpretations of ambiguous statutes than to agency legal decisions under explicit grants of interpretive authority. As the Court explained in 1981:

We consider Treasury Regulations valid if they "implement the congressional mandate in some reasonable manner." In National Muffler Dealers Assn. v. United States, 440 U.S. 472, 477 (1979), we stated: "In determining

\footnotetext{
${ }^{121}$ See supra Part II.A.2.

${ }^{122}$ Chevron U.S.A., Inc. v. NRDC, 467 U.S. 837, 843 (1984).

${ }^{123} \mathrm{Id}$. at 843-44.
} 
whether a particular regulation carries out the congressional mandate in a proper manner, we look to see whether the regulation harmonizes with the plain language of the statute, its origin, and its purpose." Harmony between statutory language and regulation is particularly significant in this case. Congress itself defined the word at issue- - wages"and the Commissioner interpreted Congress' definition only under his general authority to "prescribe all needful rules." Because we therefore can measure the Commissioner's interpretation against a specific provision in the Code, we owe the interpretation less deference than a regulation issued under a specific grant of authority to define a statutory term or prescribe a method of executing a statutory provision. Where the Commissioner acts under specific authority, our primary inquiry is whether the interpretation or method is within the delegation of authority. ${ }^{124}$

Thus, the pre-Chevron understanding was that agency interpretation of an ambiguous statute was reviewed for reasonableness-does the agency interpretation "implement the congressional mandate in a reasonable manner?" This was a less deferential standard of review than Chevron because it involved a careful look at statutory language, origins, purpose, and legislative history, and it did not presume that ambiguity meant that Congress intended to delegate lawmaking power to the agency. The final say on the correctness of interpretation of an ambiguous statute would lie with the reviewing court. With regard to an explicit delegation of interpretive authority, the agency's interpretation would be reviewed under the more deferential inquiry of whether the interpretation "is within the delegation of authority." In Chevron and another 1984 decision, the Court transformed this standard into the highly deferential "plainly" or "manifestly" contrary to the statute. ${ }^{125}$

With regard to the basis for the Court's formulation of Step Two, recall that the APA appears to presume that legal questions would be resolved by courts, not agencies. Step Two should be based either on statutory text or pre-APA principles that might have been incorporated into the APA. The Court's formulation of Step Two, however, seems to be inconsistent with the desire of the framers of the APA to rein in agencies. The Chevron Court cited cases in support of both variants of Step Two, but the case law cited did not provide much support. As noted above, in a case involving an explicit delegation of power to an agency, a week before Chevron was decided, the Court used the phrase "plainly contrary to the statute" to

\footnotetext{
${ }^{124}$ Rowan Cos., Inc. v. United States, 452 U.S. 247, 252-53 (1981) (citations omitted).

${ }^{125}$ United States v. Morton, 467 U.S. 822 (1984); Chevron, 467 U.S. at 844.
} 
describe when a reviewing court should overturn an agency interpretation. ${ }^{126}$ The other cases relied on in Chevron for the "manifestly contrary to the statute" language do not contain any similar phrase, and in fact are confusing on the status of agency interpretations under explicit delegations. For example, in 1981's Schweiker v. Gray Panthers, the Court stated:

In view of this explicit delegation of substantive authority, the Secretary's definition . . . is "entitled to more than mere deference or weight." Rather, the Secretary's definition is entitled to "legislative effect" because, "[i]n a situation of this kind, Congress entrusts to the Secretary, rather than to the courts, the primary responsibility for interpreting the statutory term.” Although we do not abdicate review in these circumstances, our task is the limited one of ensuring that the Secretary did not "excee[d] his statutory authority" and that the regulation is not arbitrary or capricious. ${ }^{127}$

This pre-Chevron passage is notable for three separate ideas that are highly relevant under Chevron. First, the Court equates legislative intent to confer the status of law on agency interpretations with a high degree of deference to agency interpretations, ${ }^{128}$ although it does not provide much guidance on how deferential a court should be in determining whether the Secretary "exceeded his statutory authority." Second, it is consistent with Chevron's notion that in a case of explicit delegation, Congress assigned primary interpretive authority to the agency. Third, it states that even if the interpretation is found to be within the agency's statutory authority, there should be an additional inquiry into whether the choice of interpretation is arbitrary or capricious. This third element has been urged by some, but it is not clear whether it is proper practice under Chevron.

In another decision relied upon in Chevron for the construction of Step Two, 1977's Batterton v. Francis, ${ }^{129}$ the Court stated a standard of review similar to that of Gray Panthers, while accurately quoting the statutory language. "The regulation at issue in this case is therefore entitled to more than mere deference or weight. It can be set aside only if the Secretary exceeded his statutory authority or if the regulation is 'arbitrary, capricious, an abuse of discretion, or otherwise not in accordance with law." "130 The final case relied on in Chevron for the establishment of the

\footnotetext{
${ }^{126} \mathrm{Id}$. at 834. original).

${ }^{127}$ Schweiker v. Gray Panthers, 453 U.S. 34, 44 (1981) (citations omitted) (alterations in

${ }^{128}$ This is the Mead issue. See infra Part II.B.3.

${ }^{129} 432$ U.S. 416, 425 (1977).

${ }^{130}$ Id. at 426 (quoting 5 U.S.C. § 706(2)(A), (C)).
} 
"manifestly contrary to the statute" standard for reviewing explicit delegations, the pre-APA American Telephone \& Telegraph Co. v. United States, ${ }^{131}$ does not support it at all, but is about deference to policy decisions. It does mention that the agency must remain within its statutory authority but it does not discuss further the standard the reviewing court should apply when determining whether an agency has done so. ${ }^{132}$ Thus, at best there are hints of the explicit delegation branch of Chevron Step Two going back to 1977, but apparently not before. There is certainly no pre-Chevron support for treating ambiguous statutes as implicit delegations of interpretive authority to agencies.

The "permissible" or "reasonable" construction standard for reviewing agency interpretations of ambiguous statutory provisions, when the delegation of agency interpretive authority is implicit, appears to be more consistent with the general practice under the APA, although perhaps not in the highly deferential way that it has been understood since Chevron. Numerous cases that arose after the passage of the APA and before Chevron applied the reasonable construction or reasonable interpretation standard of review to agency interpretations of ambiguous statutes. ${ }^{133}$ These cases looked carefully at statutory text, purpose, and history, which may not be the case in post-Chevron Step Two decisions. In many cases, however, courts went even further and used the phrase "reasonable construction" or "reasonable interpretation" as a synonym for "correct construction.” 134 This indicates that these phrases did not have a settled meaning in the period before Chevron.

The tradition, however, is less clear before the APA. Many pre-APA cases use the terms "reasonable interpretation" and "reasonable construction," but in most contexts these phrases seem to mean the correct interpretation or the best interpretation in light of the circumstances. ${ }^{135}$

\footnotetext{
131299 U.S. 232, 236 (1936)

${ }^{132} \mathrm{Id}$.

${ }^{133}$ See, e.g., EPA v. Nat'l Crushed Stone Ass'n, 449 U.S. 64, 84 (1980) (“[W]e believe that the Administrator has adopted a reasonable construction of the statutory mandate.” (emphasis added)).

${ }^{134}$ See, e.g., FTC v. Fred Meyer, Inc., 390 U.S. 341, 357 (1968) (rejecting the FTC’s reading of a statute in favor of what it found to be "the most reasonable construction of" the statute). For additional cases using this language in various senses, see Ky. Dep’t of Educ. v. U.S. Dep’t of Educ., 717 F.2d 943, 948 (6th Cir. 1983) (using the "reasonable interpretation" language in the context of legislation regarding school district’s usage of funds); Hart \& Miller Islands Area Evntl. Group v. Corps of Eng'rs of U.S. Army, 621 F.2d 1281, 1289 (4th Cir. 1980) (applying the "reasonable construction" of a statute regarding works that span waterways); Holliday v. Ketchum, MacLeod \& Grove, Inc., 584 F.2d 1221, 1228 (3d Cir. 1978) (finding that a "reasonable construction" of the ADEA affords complainants a choice of forum).

${ }^{135}$ See Harris v. Zion Sav. Bank \& Trust Co., 317 U.S. 447, 453 (1943) ("[T]he rule comports with what we have endeavored to show is the natural and reasonable construction of [the statute].”); Harrison v. Schaffner, 312 U.S. 579, 581 (1941) ("[T] dependent upon . . . the import and reasonable construction of the taxing act.”). In some cases, however, "reasonable interpretation" was used to denote an interpretation within an allowable statutory range that was also rational as a matter of policy. See Mother Lode Coal. Mines Co. v. Helvering, 317
} 
The Hearst case, for example, used the phrase "reasonable basis in law" to denote a deferential standard of review in cases involving the application of an ambiguous legal standard to a particular situation, which is different from a pure question of statutory interpretation. ${ }^{136}$ At least in the years immediately prior to the enactment of the APA, there was no clear understanding that there should be deference to agency interpretations of ambiguous statutes under a reasonable interpretation standard.

Since Chevron, the Court has applied the "reasonable construction" standard numerous times in cases involving ambiguous statutes. ${ }^{137}$ Express delegations of interpretive power are rarer, and therefore the Court has not had many occasions to apply the "manifestly contrary to the statute" standard to such delegations. Adding to the confusion, the Court has gone so far as to cast the "manifestly contrary" standard as the standard for reviewing all policy decisions made by agencies with rulemaking authority, not only decisions involving statutory interpretation. ${ }^{138}$ And in some instances, the Court has applied it in cases of ambiguity, ${ }^{139}$ which are supposed to be governed by the "reasonable or permissible construction" standard.

Perhaps this all indicates that the Court does not perceive any real differences among these situations or standards of review. It may also be

U.S. 222, 225 (1942) (noting that the meaning given is "practically compelled by the words" of the statute and also a "reasonable interpretation"). "Reasonable construction" was also used to denominate the correct interpretation of a clause in a contract. See Ill. Steel Co. v. Balt. \& Ohio R.R. Co., 320 U.S. 508, 515-16 (1944). Sometimes it is not possible to discern whether the Court is using "reasonable" to mean "correct" or simply within a permissible statutory range. See Nat'l Lead Co. v. United States, 252 U.S. 140, 145 (1920). National Lead is particularly interesting because it involves judicial review of an agency determination.

${ }^{136}$ NLRB v. Hearst Publ'ns, Inc., 322 U.S. 111, 131 (1944).

${ }^{137}$ The Court's general statements of the standard of review under Chevron Step Two have not been particularly illuminating and have at times even appeared to be circular. For example, in an early Step Two case, the Court stated that the test is whether the agency interpretation is "sufficiently rational ... to preclude a court from substituting its judgment for that of [the agency]." Young v. Cmty. Nutrition Inst., 476 U.S. 974, 981 (1986) (citations omitted) (alteration in original).

${ }^{138}$ See ABF Freight Sys., Inc. v. NLRB, 510 U.S. 317, 324 (1994) ("When Congress expressly delegates to an administrative agency the authority to make specific policy determinations, courts must give the agency's decision controlling weight unless it is 'arbitrary, capricious, or manifestly contrary to the statute.”' (quoting Chevron U.S.A., Inc. v. NRDC, 467 U.S. 837, 844 (1984))). The full quote from Chevron indicates that the Court there was addressing agencies filling statutory gaps, not making policy under statutory standards:

If Congress has explicitly left a gap for the agency to fill, there is an express delegation of authority to the agency to elucidate a specific provision of the statute by regulation. Such legislative regulations are given controlling weight unless they are arbitrary, capricious, or manifestly contrary to the statute. Chevron, 467 U.S. at 843-44 (emphasis added).

${ }^{139}$ See Household Credit Servs., Inc. v. Pfennig, 541 U.S. 232, 242 (2004) (“Because § 1605 is ambiguous, the Board's regulation implementing $\S 1605$ 'is binding in the courts unless procedurally defective, arbitrary or capricious in substance, or manifestly contrary to the statute.'” (quoting United States v. Mead Corp., 533 U.S. 218, 227 (2001))). In Smiley, the Court appears to use the two standards - reasonable interpretation and manifestly contrary to the statute-interchangeably. See Smiley v. Citibank, 517 U.S. 735, 742-47 (1996). 
due to the view expressed in some opinions that when Congress grants an agency rulemaking authority, all ambiguities become express delegations of interpretative power. ${ }^{140}$ This is certainly not consistent with the text or original understanding of Chevron, nor with the numerous pre-Chevron cases in which the reasonable or permissible construction standard is applied to agencies with rulemaking power. This means that there may be a third category not originally captured by Chevron - when an agency that has been granted the power to make legislative rules makes new law designed to implement a statutory provision, the "manifestly contrary to the statute" standard is applied to determine whether the agency has acted within statutory constraints. ${ }^{141}$ Whatever one thinks of these various permutations of Chevron Step Two, one thing seems clear-the Court has not succeeded in creating a clear and easy to administer standard of review for agency interpretations of law. ${ }^{142}$

Another problem with the Chevron doctrine is that the Court is unclear about the relevance of legislative history and policy to judicial review of interpretive decisions. The Chevron opinion contains two separate discussions of legislative history. The first, Part V of the Court's opinion, is a brief demonstration that the legislative history does not directly address the issue in the case, namely whether Congress intended to foreclose the plant-wide definition of stationary source. ${ }^{143}$ This discussion is consistent with "traditional tools Chevron," given that legislative history is one of the traditional tools of statutory interpretation. The second occurs in Part VII of the opinion in which the Court refutes the NRDC's arguments based on statutory text, legislative history, and policy. ${ }^{144}$ This second discussion repeats the conclusion that the legislative history is "unilluminating" and rejects the argument that because the EPA has changed its definition, its interpretation is not entitled to deference.

${ }^{140}$ See Ragsdale v. Wolverine World Wide, Inc., 535 U.S. 81, 102 (2002) (O’Connor, J., dissenting); see also Sullivan v. Zebley, 493 U.S. 521, 528 (1990) ("Since the Social Security Act expressly grants the Secretary rulemaking power . . . 'our review is limited to determining whether the regulations promulgated exceeded the Secretary's statutory authority and whether they are arbitrary and capricious.'” (quoting Bowen v. Yuckert, 482 U.S. 137, 145 (1987))).

${ }^{141}$ For example, in a 1997 opinion, the Court characterized review under the SEC's broad rulemaking authority as follows:

Because Congress has authorized the Commission ... to prescribe legislative rules, we owe the Commission's judgment "more than mere deference or weight." Therefore, in determining whether [the rule] is reasonably designed to prevent fraudulent acts, we must accord the Commission's assessment "controlling weight unless [it is] arbitrary, capricious, or manifestly contrary to the statute.” In this case, we conclude, the Commission's assessment is none of these.

United States v. O’Hagan, 521 U.S. 642, 673 (1997) (quoting Batterton v. Francis, 432 U.S. 416, 42426 (1977), and Chevron, 467 U.S. at 844).

${ }^{142}$ See Jellum, Which Is To Be Master, supra note 57, at 760 ("There is no consistency, just a muddy battlefield.”).

${ }^{143}$ Chevron, 467 U.S. at 851.

${ }^{144}$ Id. at $859-66$. 
Overall, the discussion of legislative history fits pretty well with a traditional tools version of Chevron Step One and, because legislative history does not seem relevant to whether an interpretation is manifestly contrary to the statute, a reasonable interpretation version of Chevron Step Two.

Chevron's discussion of policy is more consistent with original, directly spoken Chevron than with subsequent, less deferential, iterations of the Chevron standard. The Court characterized NRDC's policy arguments as an attempt to refight a policy battle that it lost at the agency level and in the states that implemented that decision, but that was never brought to Congress's attention. The Court then stated that the policy arguments should be addressed to the agency and to Congress but not to the courts. The Court concluded strongly that, at least when a "regulatory scheme is technical and complex, [w] hen a challenge to an agency construction of a statutory provision . . . really centers on the wisdom of the agency's policy, rather than whether it is a reasonable choice within a gap left open by Congress, the challenge must fail." 145 This is extremely deferential, since it seems to say that policy decisions made within a gap left by Congress will not even be reviewed under the arbitrary, capricious standard.

The possible abdication of review of the wisdom of agency interpretation raises the lingering issue of the relevance of the arbitrary or capricious standard. Does the Court mean to foreclose reversal of an agency choice even if, on a fair assessment of its wisdom, the Court would find it to be arbitrary or capricious? This seems to be contrary to the preChevron cases discussed above, and to some recent formulations of the Chevron standard, in which the Court specifically referred to the possibility that an agency policy choice under an explicit delegation might be rejected as arbitrary or capricious. ${ }^{146}$ Perhaps the problem is that if it is really an interpretation, and if it falls within the statutory bounds and goals established by Congress, then it cannot be arbitrary or capricious since, as the Court has recently stated, the wisdom of an agency policy is judged against the statutory provisions enacted by Congress. ${ }^{147}$ If Congress includes unwise choices within the range of interpretations that are permissible or not manifestly contrary to the statute, then the courts should

\footnotetext{
${ }^{145} \mathrm{Id}$. at 865,866 .

${ }^{146}$ Household Credit Servs., Inc. v. Pfennig, 541 U.S. 232, 242 (2004).

${ }^{147}$ See, e.g., Massachusetts v. EPA, 549 U.S. 497, 534-35 (2007) (the wisdom of agency policy is judged against statutory standards). Ron Cass argues that any measure of deference to the EPA's judgment on the appropriate exercise of its statutory discretion would have resulted in affirmance of the agency's decision not to regulate greenhouse gases as air pollutants. See Ronald A. Cass, Massachusetts v. EPA; The Inconvenient Truth About Precedent, 93 VA. L. REV. IN BRIEF 75, 83 (2007). While Cass may be correct, it remains unclear how Chevron is relevant to the policy question of whether, assuming jurisdiction, the agency ought to regulate greenhouse gases at this time.
} 
approve the agency interpretation, perhaps with some advice to Congress.

\section{Multiple Chevrons}

Perhaps the greatest problem in the application of the Chevron doctrine is that the Court very quickly abandoned the original, apparently highly deferential, version of the doctrine and replaced it with multiple versions that, if followed, can lead to different results. The Chevron doctrine has basically disappeared and lacks the content necessary to remain a viable decision procedure. ${ }^{148}$ I call the various versions of Chevron that currently exist "original directly spoken Chevron," "traditional tools Chevron," "plain meaning Chevron," and "extraordinary cases Chevron." Each of these versions of Chevron is currently applied by the Supreme Court, except perhaps original directly spoken Chevron, which may rarely, if ever, be applied. ${ }^{149}$ What has occurred is that the results of judicial review of agency statutory interpretation before and after Chevron, especially at the Supreme Court, are virtually indistinguishable, meaning that the effort to increase deference to agencies and clarity in the law has failed.

"Original directly spoken to" Chevron is the version of Chevron most clearly stated in the Chevron opinion itself. Under this doctrine, a case would be resolved under Chevron Step One only if "Congress has directly spoken to the precise question at issue." "150 In Chevron itself, this would have meant that for the case to have been resolved in Step One, Congress would have had to have addressed the exact issue of whether the definition of "stationary source" could include treating an entire plant with numerous air pollution emitting installations as a single stationary source. This version of Chevron Step One is very narrow, which means that under it, deference to agencies would increase substantially as more cases made it past Step One and into the highly deferential Step Two. It is also relatively clear and easy to apply-only the most direct evidence of intent on the specific subject would result in a decision under Step One, and the vast majority of cases would easily end up in Step Two. For example, the statutory analysis in the Chevron opinion is only four paragraphs long and, with footnotes, only about four hundred words. It does not decide the meaning of "stationary source" but merely concludes that the statute does not specifically answer the question in the case.

Whether one agrees or disagrees with the original Chevron, had it remained the law it would have dramatically changed review of agency statutory interpretation and it would have substantially simplified the

\footnotetext{
${ }^{148}$ For a different take on how Chevron has evolved over the years, see Jellum, Chevron's Demise, supra note 83.

${ }^{149}$ See Gifford, supra note 64, at 798-801 (2007) (describing the "instability" of the original Chevron doctrine).

${ }^{150}$ Chevron, 467 U.S. at 842.
} 
process of such review. Courts would have been required to defer to agency interpretations except in the most rare case of agency defiance of a precise statutory directive.

The seeds of the destruction of original directly spoken Chevron were sown in a footnote in Justice Stevens's Chevron opinion itself which stated:

The judiciary is the final authority on issues of statutory construction and must reject administrative constructions which are contrary to clear congressional intent. If a court, employing traditional tools of statutory construction, ascertains that Congress had an intention on the precise question at issue, that intention is the law, and must be given effect. $^{151}$

This language allows for a potentially broader Step One-rather than require that Congress have "directly spoken" to the precise question, it requires that Congress "had an intention" on the "precise" question. The key to whether this footnote amounts to a major expansion of the scope of Chevron Step One may lie in the word "precise," and as we shall see, the word "precise" has since disappeared from the traditional tools lexicon, severely reducing the scope of deferential Chevron Step Two.

Shortly after Chevron was decided, in another opinion by Justice Stevens, the Court seized on this "traditional tools" language and began its discussion, this time in text rather than in a footnote, of the standard of review as follows: "The question whether Congress intended the two standards to be identical is a pure question of statutory construction for the courts to decide. Employing traditional tools of statutory construction, we have concluded that Congress did not intend the two standards to be identical." 152 This has evolved into what this Article refers to as "traditional tools Chevron," in which the Court uses statutory construction devices that pre-date Chevron to determine Congress's meaning in Chevron Step One.

The best example of traditional tools Chevron is the Court's opinion in Dole v. United Steelworkers of America, Inc. ${ }^{153}$ In that case, the Court began its discussion of the standard of review for statutory questions as follows: "On a pure question of statutory construction, our first job is to try to determine congressional intent, using traditional tools of statutory construction." 154 The word "precise" does not appear in the majority opinion, so that the determination of congressional intent at Step One

${ }^{151} \mathrm{Id}$. at $843 \mathrm{n} .9$ (citations omitted).

${ }^{152}$ INS v. Cardoza-Fonseca, 480 U.S. 421, 446 (1987).

153494 U.S. 26 (1990).

${ }^{154}$ Id. at 35 (quoting NLRB v. United Food \& Commercial Workers Union, 484 U.S. 112, 123 (1987)). 
appears to have evolved into a pre- or non-Chevron practice for determining congressional intent. The factors the Court has considered under traditional tools Chevron include statutory text, statutory object and structure, canons of interpretation, relationship with other statutes, consistency of agency interpretation, and legislative history. A court using these tools for discovering Congress's intent is much more likely to decide the case in Step One than under original directly spoken Chevron. Because deference to agency views occurs only in Chevron Step Two, expanded Step One entails reduced deference. Perhaps the icing on the cake was that the majority opinion did not cite Chevron itself until the very end of the opinion, and then only for the anti-deference point that "[i]f the intent of Congress is clear, that is the end of the matter."155

Justice Stevens has also used the characterization of an issue as a "pure question of statutory construction" to argue that Chevron deference should not apply at all since pure questions of statutory construction are for the courts. For example, very recently in Negusie v. Holder, ${ }^{156}$ Justice Stevens, in dissent, argued that the question in the case is a "pure question of statutory construction for the courts to decide."157 Thus, rather than remand the case to the agency for a proper construction of the statute as the majority had done, he would have had the Court construe the statute and remand the case to the agency only for an application of the statute to the particular facts. $^{158}$

As is easy to imagine, the proponents of Chevron deference have not been happy with the expansive traditional tools version of Step One. They correctly understand it to seriously undermine deference to agencies on questions of statutory interpretation. Justice Scalia, joined by Chief Justice Rehnquist and Justice O'Connor, wrote in a concurring opinion in one traditional tools decision:

I join the Court's opinion, and write separately only to note that our decision demonstrates the continuing and unchanged vitality of the test for judicial review of agency determinations of law set forth in [Chevron]. Some courts have mistakenly concluded otherwise, on the basis of dicta in

\footnotetext{
${ }^{155}$ Id. at 43 (citing Chevron, 467 U.S. at 842-43).

156129 S. Ct. 1159 (2009).

${ }^{157}$ Id. at 1170 (Stevens, J., dissenting) (quoting Cardoza-Fonseca, 480 U.S. at 446).

${ }^{158}$ The agency and lower court had interpreted a prior decision, Fedorenko v. United States, 449 U.S. 490 (1981), to require a particular interpretation. The Supreme Court disagreed with this interpretation of its decision in Fedorenko, which, under Brand $X$, left the agency free to arrive at a different interpretation. The Court remanded to allow the agency to interpret the statute, with the understanding that the interpretation would then be subject to review under Chevron Step Two. Negusie v. Holder, 129 S. Ct. 1159, 1163 (2009). The cases involved situations under which immigrants applying for asylum based on fears of persecution are disqualified for being persecutors themselves. Fedorenko, 449 U.S. at 493; Negusie, 129 S. Ct. at 1162-63.
} 
INS v. Cardoza-Fonseca. ${ }^{159}$

Even Justice Scalia, however, has not confined himself to original directly spoken Chevron when deciding cases in Chevron Step One. Instead, he has applied what this Article refers to as "plain meaning Chevron" in which the Court decides a case in Chevron Step One using only one of the traditional tools of statutory interpretation, namely the plain meaning rule. This is in keeping with Justice Scalia's self-assessment that he is more likely than other judges to find clear statutory meaning. ${ }^{160}$

The best example of Justice Scalia's application of "plain meaning" Chevron Step One is his opinion for the Court in MCI v. AT\&T. ${ }^{161}$ The issue in that case was whether the FCC had the power to prohibit nondominant long distance telephone carriers (i.e., everyone but AT\&T) from filing tariffs with the FCC. The Telecommunications Act gives the FCC the power to "modify" its provisions, and the FCC claimed that de-tariffing nondominant carriers was a modification of the Act's tariff provisions. ${ }^{162}$ Justice Scalia's opinion rejecting the FCC's reading of the statute relied primarily on the plain meaning of the word "modify," which he found to mean moderate, not fundamental, change. ${ }^{163}$ He also found that tariff filing was the heart of the regulatory scheme, so that de-tariffing any carrier was more than a moderate change. Justice Scalia derived the meaning of "modify" from dictionaries, and the opinion rejected a single dictionary that included a "fundamental change" as a meaning of modify. ${ }^{164}$ The opinion's discussion of the meaning of "modify" did not refer to any other tool of statutory interpretation, such as legislative history, ${ }^{165}$ statutory structure and purpose, or canons of construction, and in fact it rejected using the underlying policy of the provision, stating "our estimations, and the Commission's estimations, of desirable policy cannot alter the meaning of the federal Communications Act of 1934.”166 This

${ }^{159}$ United Food \& Commercial Workers Union, 484 U.S. at 133 (Scalia, J., concurring).

${ }^{160}$ See supra note 67; see also Jellum, Chevron's Demise, supra note 83, at 748-51.

${ }^{161}$ MCI Telecomms. Corp. v. Am. Tel. \& Tel. Co. (MCI v. AT\&T), 512 U.S. 218, 225-27 (1994).

${ }^{162}$ Id. at 224-25.

${ }^{163} \mathrm{Id}$. at 225.

${ }^{164}$ Id. at 225-27, 226 n.2.

${ }^{165}$ Justice Scalia is an outspoken opponent of using legislative history. See ANTONIN SCALIA, A MATTER OF INTERPRETATION: FEDERAL COURTS AND THE LAW 31-36 (1997) (arguing that legislative history should not be used because it is not a "proper criterion of the law"); see also Blanchard v. Bergeron, 489 U.S. 87, 97-98 (1989) (Scalia, J., concurring in part and concurring in the judgment) ("That the Court should refer to the citation of three District Court cases in a document issued by a single committee of a single house as the action of Congress displays the level of unreality that our unrestrained use of legislative history has attained.").

${ }^{166}$ MCI v. AT\&T, 512 U.S. at 234. The Court did, however, look at the overall structure of the Act to determine that eliminating the tariff requirement would be more than a moderate change, but this was not to discover the meaning of the statute but rather to apply the meaning arrived at to the situation. Thus, I disagree with Cass Sunstein's characterization of MCI $v$. AT\&T as an example of extraordinary cases Chevron. Cass R. Sunstein, Chevron Step Zero, 92 VA. L. REV. 187, 236-37 (2006). 
variant of Chevron Step One is broader than original directly spoken Chevron because it does not require that Congress have answered the precise question in so many words, but it is narrower than traditional tools Chevron because it confines the search for congressional intent to the plain meaning of the statutory language.

The final Chevron variant is "extraordinary cases Chevron," in which the reviewing court finds clear congressional intent outside the Chevron framework in extraordinary cases. The cases are extraordinary because of the importance of the issue, at least as related to the regulatory scheme. The best example of extraordinary cases Chevron is the Court's decision that the Food and Drug Administration ("FDA") lacks the power to regulate the marketing of tobacco products under the Federal Food, Drug and Cosmetic Act. ${ }^{167}$ Although Congress had not directly spoken to the precise question at issue (whether the FDA had jurisdiction to regulate tobacco marketing) and the plain meaning of the statute seemed to support jurisdiction (cigarettes and other tobacco products were within the plain meaning of drugs and drug delivery devices), the Court found that the FDA lacked jurisdiction because of the unique legal history surrounding tobacco which indicated that Congress did not intend the general language of the Act to grant the FDA jurisdiction over tobacco. ${ }^{168}$ The Court observed:

This is hardly an ordinary case. ... Owing to its unique place in American history and society, tobacco has its own unique political history. Congress, for better or for worse, has created a distinct regulatory scheme for tobacco products, squarely rejected proposals to give the FDA jurisdiction over

${ }^{167}$ FDA v. Brown \& Williamson Tobacco Corp., 529 U.S. 120, 142-43 (2000). Cass Sunstein places MCI v. AT\&T and Babbit v. Sweet Home Chapter of Communities for a Great Oregon, into the extraordinary cases Chevron category. Sunstein, supra note 166, at 236-40. In my view, the dominant analysis of each of those cases does not fit easily into the extraordinary cases doctrine. In MCI $v$. $A T \& T$, plain meaning analysis dominates, although the Court's discussion of the importance of tariff filing is consistent with extraordinary cases analysis. MCI v. AT\&T, 512 U.S. at 225-28. Babbitt, which involved whether the Endangered Species Act's prohibition on taking an endangered species could be read to include habitat destruction, is best understood as a traditional tools Chevron decision, with focus on statutory text, broad purposes and the relationship of the provision at issue to other provisions in the statute. Babbitt v. Sweet Home Chapter of Cmtys. for a Great Or., 515 U.S. 687, 697-701 (1995). Justice Scalia's dissent in that case is a prime example of a plain meaning Chevron argument. Id. at 717-21 (Scalia, J., dissenting). Abby Moncrieff has argued that proper application of "extraordinary cases" Chevron would have led the Court in Massachusetts v. EPA to reject EPA authority to regulate greenhouse gas emissions from automobiles. See Abigail Moncrieff, Reincarnating the "Major Questions" Exception to Chevron Deference as a Doctrine of Noninterference (Or Why Massachusetts v. EPA Got It Wrong), 60 ADMIN. L. REv. 593, 603-06 (2008) (arguing that the Court should have found that the EPA lacks jurisdiction over global warming gases).

${ }^{168}$ Brown \& Williamson Tobacco Corp., 529 U.S. at 141-43. The Court also relied on a conventional traditional tools argument based on the structure of the Act, as follows: The Act requires the FDA to ban any product that is not safe and effective for its intended purpose. Tobacco products are unsafe. Therefore, if the FDA had jurisdiction over tobacco products, it would be legally bound to ban them, which Congress clearly did not intend, and which the FDA did not argue for. Id. 
tobacco, and repeatedly acted to preclude any agency from exercising significant policymaking authority in the area. Given this history and the breadth of the authority that the FDA has asserted, we are obliged to defer not to the agency's expansive construction of the statute, but to Congress' [sic] consistent judgment to deny the FDA this power. ${ }^{169}$

In a sense, the extraordinary cases version of Chevron is a device for deciding the case in Step One when ordinary statutory interpretation principles point toward a meaning contrary to the Court's view of Congress's true intent. ${ }^{170}$

The existence of these four variants of Chevron epitomizes what is wrong with the doctrine and why it should be abandoned. The range of possible reasons for deciding a case in Chevron Step One is so broad that almost any case can be so decided, which means there is no deference to the agency. Further, the Court can choose to ignore traditional indications of congressional intent and decide based on either whether Congress has directly addressed the precise issue or on whether the case is extraordinary and should be decided on a sui generis evaluation of likely congressional intent. In such cases, the Chevron framework itself has dissolved into the mist.

Further, the variants are so different from each other that from a lawyer's perspective, Chevron has become a moving target. Should a lawyer arguing a case address whether Congress has directly spoken to the precise issue in question, whether Congress's intent can be discerned using traditional tools or the plain meaning rule, or whether the particular case is so extraordinary that it should be taken out of the methodology altogether? Apparently, a competent lawyer should address all of these possibilities, unless somehow it becomes easy to predict which variant a court will apply in a particular case.

\section{When Chevron Applies: Chevron Step Zero}

Because the Chevron doctrine appears to create a remarkably strong form of deference, agencies have a powerful incentive to argue, whenever plausible, that their interpretations should be evaluated under Chevron. ${ }^{171}$ Thus, although the Chevron opinion on its face appears to create a standard for review of all questions of statutory construction decided by

\footnotetext{
${ }^{169} \mathrm{Id}$. at $159-60$.

${ }^{170}$ For an additional case that may fit into the extraordinary cases version of Chevron, see Gonzales v. Oregon, 546 U.S. 243, 267-68 (2006) ("The importance of the issue of physician-assisted suicide . . . makes the oblique form of the claimed delegation all the more suspect.”).

${ }^{171}$ This Article uses "appears" because in many cases, this appearance is not the reality.
} 
administrative agencies, ${ }^{172}$ the Court found it necessary to create a doctrine to determine when it applies. ${ }^{173}$ Without a limiting doctrine, agencies could use Chevron strategically, issuing ill-considered interpretations as litigation positions to receive extraordinary deference if the statute contained a gap or was ambiguous.

The jurisprudence governing the scope of Chevron has been dubbed "Chevron Step Zero" because the determination of whether Chevron applies is made prior to applying Chevron Steps One and Two. ${ }^{174}$ The Court's decisions on whether Chevron applies are deeply flawed, primarily because they disavow any legal content. Justice Souter's opinion for the Court in United States v. Mead Corp. ${ }^{175}$ the leading case on the scope of deference, is the prime example. ${ }^{176}$ Mead involved whether tariff classifications issued relatively informally, but treated by the agency as binding between it and the party whose product has been classified, should receive Chevron deference. Justice Souter catalogued the factors that the Court has found relevant to whether an agency's interpretation should receive Chevron deference, but he was careful not to characterize any factor as decisive. Consider the care with which the following passage is constructed to avoid containing any actual binding law:

We have recognized a very good indicator of delegation meriting Chevron treatment in express congressional authorizations to engage in the process of rulemaking or adjudication that produces regulations or rulings for which deference is claimed. It is fair to assume generally that Congress contemplates administrative action with the effect of law when it provides for a relatively formal administrative procedure tending to foster the fairness and deliberation that

\footnotetext{
${ }^{172}$ Except perhaps for those that can be characterized as "pure question[s] of statutory interpretation" which are "for the courts to decide." INS v. Cardoza-Fonseca, 480 U.S. 421, 446 (1987).

${ }^{173}$ Before the APA was enacted, there was a convention that when Congress provided a penalty for violating an agency rule, it was understood that Congress intended the agency rule to have the force of law. See Thomas W. Merrill \& Kathryn Tongue Watts, Agency Rules with the Force of Law: The Original Convention, 116 HARV. L. REv. 467, 472 (2002). Dick Pierce has argued against limiting the applicability of Chevron deference to a subset of agency interpretation on the ground that this would limit the realization of the democracy and accountability enhancing goals of the doctrine. Pierce, supra note 61 , at $562-65$.

${ }^{174}$ See Sunstein, supra note 166, at 191 (describing "Step Zero" as "the initial inquiry into whether the Chevron framework applies at all"). The disagreement over the number of steps in Chevron is discussed infra Part II.B.5.

${ }^{175} 533$ U.S. 218, 227-34 (2001).

${ }^{176}$ Other decisions on the scope of Chevron, rendered both before and after Mead, do not make the doctrine any clearer. See, e.g., Barnhart v. Walton, 535 U.S. 212, 217-22 (2002) (noting that while Chevron deference will normally apply in cases of statutorily prescribed rulemaking or adjudication, the lack of formal process in an agency's decision making did not bar the application of Chevron); Christensen v. Harris County, 529 U.S. 576, 586-88 (2000) (holding Chevron deference not warranted with regard to opinion letters, policy manuals, and other decisions lacking force of law).
} 
should underlie a pronouncement of such force. Thus, the overwhelming number of our cases applying Chevron deference have reviewed the fruits of notice-and-comment rulemaking or formal adjudication. That said, and as significant as notice-and-comment is in pointing to Chevron authority, the want of that procedure here does not decide the case, for we have sometimes found reasons for Chevron deference even when no such administrative formality was required and none was afforded. The fact that the tariff classification here was not a product of such formal process does not alone, therefore, bar the application of Chevron. ${ }^{177}$

Note that the Court says that notice and comment does not automatically qualify an agency decision for Chevron deference and the absence of notice and comment does not automatically disqualify an agency decision from receiving Chevron deference. The question whether any particular agency decision should receive Chevron deference is whether Congress intends that the agency be able to speak with the force of law, with rulemaking power being a "very good indicator" of such intent. In Mead, the Court found a lack of congressional intent to endow tariff classification rulings with the force of law for several reasons. First, the legislation itself did not indicate that Congress intended tariff rulings to have the force of law. The statute did authorize the agency to promulgate procedural regulations, and it referred to the tariff classifications as "binding rulings," but the reference to "binding rulings" according to the Court meant that the rulings were binding between the agency and the particular party, not binding on third parties which would give them legislative effect. ${ }^{178}$ In fact, the agency had disavowed any effect on third parties. $^{179}$

In addition to the lack of congressional intent for the customs rulings to have the force of law, the Court relied on several additional factors for declining to confer Chevron deference on the rulings. These factors

\footnotetext{
${ }^{177}$ Mead, 533 U.S. at 229-31 (citations and footnotes omitted).

${ }^{178} \mathrm{Id}$. at 232.

${ }^{179}$ Id. at 232-33. The Court noted:

It is true as well that Congress had classification rulings in mind when it explicitly authorized, in a parenthetical, the issuance of "regulations establishing procedures for the issuance of binding rulings prior to the entry of the merchandise concerned." The reference to binding classifications does not, however, bespeak the legislative type of activity that would naturally bind more than the parties to the ruling, once the goods classified are admitted into this country. . . . Customs has regarded a classification as conclusive only as between itself and the importer to whom it was issued, and even then only until Customs has given advance notice of intended change. Other importers are in fact warned against assuming any right of detrimental reliance.

Id. (quoting 19 U.S.C. § 1502(a) (2006); citing 19 CFR § 177.9(a), (c) (2000)) (footnotes omitted).
} 
include the fact that customs rulings are issued without notice and comment, by forty-six different field offices, at a rate of over 10,000 per year, and are subject to "independent" judicial review by the Court of International Trade. ${ }^{180}$

In effect, the decision in Mead complicates the presumption underlying Chevron that when a statute is ambiguous or contains a gap, Congress intends the agency to be the primary interpreter, subject to judicial review for reasonableness. ${ }^{181}$ After Mead, the presumption regarding congressional intent is not valid unless Congress provides an additional indication, such as authority to issue legislative rules, that it intends to confer lawmaking power on the agency. The greatest problem with the Mead opinion is that it does not provide any certainty regarding what additional indications are required. Rather, by merely reciting a laundry list of factors that have been found relevant in prior cases, the Court invites protracted litigation over every plausible claim for and against Chevron deference.

Justice Scalia's dissent in Mead contains a devastating critique of the majority opinion. His main point is the one discussed above, that the Court's decision does not contain any legal rule that can be applied or relied upon in the future. ${ }^{182}$ In his view, Mead is likely to cause a great deal of confusion for the parties subject to it and the lower court judges

${ }^{180}$ This last point, that judicial review is "independent" is a very sloppy characterization of judicial review of tariff rulings. The applicable statutory language, 28 U.S.C. §§ 2639-2640 (2000), provides that the agency action reviewed is presumed to be correct, that the burden is on the challenger to establish its incorrectness by clear and convincing evidence, and that the standard of review is supplied by the APA, 5 U.S.C. § 706 (2006). What Justice Souter meant by "independent" is unclear since judicial review under this provision, if it differs from judicial review generally, is somewhat less deferential than usual given the presumption of correctness and the clear and convincing evidentiary standard. Further, the Court has elsewhere found that a non-deferential standard of judicial review is not a basis for denying legal determinations Chevron deference, further undercutting this basis for denying Chevron status to the agency ruling in Mead. See United States v. Haggar Apparel Co., 526 U.S. 380, 390-92 (1999) (concluding that a statute authorizing further proceedings in the Court of International Trade to reach "correct decisions" is not inconsistent with Chevron deference). Haggar is discussed further in Merrill \& Hickman, supra note 2, at 840-41 ("The Court [in Haggar] was willing to assume that Congress has the power ... to spell out unambiguously that questions of law as well as questions of fact were to be decided de novo.”).

${ }^{181}$ For an effective critique of Mead, see Lisa Schultz Bressman, How Mead Has Muddled Judicial Review of Agency Action, 58 VAND. L. ReV. 1443, 1458-75 (2005) [hereinafter Bressman, Mead].

${ }^{182}$ Somewhat inconsistently, Justice Scalia has on more than one occasion accused the Court of either requiring some sort of formal procedure such as notice and comment rule making for Chevron deference or of recognizing notice and comment rule making as a "safe harbor" for Chevron deference. See, e.g., Nat'l Cable \& Telecomm. Ass'n v. Brand X Internet Servs., 545 U.S. 967, 1015 (2005) (Scalia, J., dissenting). The Court explicitly disavowed any such requirement, as Justice Breyer has pointed out in response to Justice Scalia. See id. at 1014 (Breyer, J., concurring) ("The Court [in Mead] explicitly stated that the absence of notice-and-comment rulemaking did 'not decide the case,' for the Court has 'sometimes found reasons for Chevron deference even when no such administrative formality was required and none was afforded.' And the Court repeated that it 'has recognized a variety of indicators that Congress would expect Chevron deference.'” (emphasis added) (internal citations omitted)). 
charged with applying it. ${ }^{183} \mathrm{He}$ is also concerned that agencies will engage in wasteful rulemaking proceedings just to be able to claim Chevron deference for interpretations that would have otherwise been rendered less formally.

Justice Scalia's opinion suggests an alternate path: Chevron deference should apply whenever an interpretation reflects the official position of an agency on a matter that would otherwise qualify for Chevron deferencewhere there is an ambiguity, a gap, or an express delegation of interpretive authority. This reasoning applies most strongly when an interpretation is rendered by or approved by a high level official. Congressional specification of a "relatively formal procedure" such as adjudication or notice and comment rule making may be less indicative of intent to delegate power to make rules with the force of law than congressional delegation of a question directly to a Cabinet Secretary. Justice Scalia argues that Congress is more likely to intend the decisions of a high level official to have the force of law regardless of formality than the decisions of a low level administrative law judge employing formal adjudication.

Justice Scalia also attacked the Court for reviving Skidmore deference in cases in which Chevron does not apply. In the pre-APA Skidmore case, the Court concluded that agency interpretations should receive deference based on numerous factors indicating relative persuasiveness, such as the formality of procedures used, the consistency of the agency's interpretation over time, and whether agency expertise is important to the decision being reviewed. ${ }^{184}$ Skidmore, being an all things considered standard for determining how much, if any, deference an agency interpretation ought to receive, is anathema to Justice Scalia's professed preference for clear rules

${ }^{183}$ Justice Scalia's prediction has been validated by subsequent experience. See, e.g., United States v. W.R. Grace \& Co., 429 F.3d 1224, 1235 (9th Cir. 2005) (“Our decisions understandably have been conflicted as to whether Chevron deference only applies upon formal rulemaking and whether lesser deference applies in other situations.”); Wilderness Soc’y v. U.S. Fish \& Wildlife Serv., 316 F.3d 913, 921 (9th Cir. 2003) ("After Mead, we are certain of only two things about the continuum of deference owed to agency decisions: Chevron provides an example of when Chevron deference applies, and Mead provides an example of when it does not.”); Jason J. Czarnezki, An Emprical Investigation of Judicial Decisionmaking, Statutory Interpretation, and the Chevron Doctrine in Environmental Law, 79 U. COLO. L. REV. 767, 808-10 (2008) (referring to W.R. Grace and Wilderness Society in discussing "intrinsic confusion in the doctrine"); see also Criddle, supra note 63, at 1305 n.180 (discussing Mead's lack of clarity and the difficulty courts of appeals have had in applying it). Criddle argues that Chevron deference is based on five core factors:

(1) congressionally delegated authority, (2) agency expertise, (3) political responsiveness and accountability, (4) deliberative rationality, and (5) national uniformity. Contrary to conventional wisdom, none of these overlapping rationales can be properly considered redundant; since the Court decided Mead, it has consistently withheld Chevron deference when any one of these core rationales is not satisfied.

Id. at 1275. Criddle may be correct as a matter of diagnosis, but the five factors are too pliable to serve as an actual legal standard that could function as a method for discerning whether Chevron deference should apply in a particular case.

${ }^{184}$ Skidmore v. Swift \& Co., 323 U.S. 134, 140 (1944). 
over vague standards.

Merrill and Hickman, writing in 2001, noted that the Court has decided numerous cases regarding the scope of Chevron and they identified fourteen unanswered questions concerning the scope of Chevron's applicability. ${ }^{185}$ The questions identified by Merrill and Hickman linger, ${ }^{186}$ including such basic questions as whether agency interpretations rendered in adjudicatory proceedings are entitled to Chevron deference, ${ }^{187}$ whether rules exempt from notice and comment, such as interpretative rules and procedural rules, are entitled to Chevron deference, ${ }^{188}$ and whether Chevron deference can apply to an agency that lacks the power to issue legislative rules.

There are even arguments over whether some of the issues have been resolved or not. For example, one of the open issues identified by Merrill and Hickman is "[whether] Chevron appl[ies] to interpretations that modify the scope of an agency's jurisdiction? (An issue subject to a conflict in the circuits and raised, but not resolved, in Brown \& Williamson.)"189 But at least some of the Justices thought that this issue had been resolved more than ten years earlier in favor of applying Chevron to interpretations that affect an agency's jurisdiction. ${ }^{190}$ While it is correct,

\footnotetext{
${ }^{185}$ Merrill \& Hickman, supra note 2, at 849-52.

${ }^{186}$ Merrill and Hickman's fifth question, whether agencies receive Chevron deference for interpretations of their own regulations, seems to have been answered in the affirmative. Before Merrill and Hickman wrote, the Court had held that an interpretation contained in a brief, which apparently reflected a longstanding agency view, was entitled to substantial, although not Chevron, deference. See Auer v. Robbins, 519 U.S. 452, 461 (1997) ("Because the salary-basis test is a creature of the Secretary's own regulations, his interpretation of it is, under our jurisprudence, controlling unless 'plainly erroneous or inconsistent with the regulation.'” (citation omitted)). More recently, the Court has implied that an agency's interpretation of its own regulation would receive Chevron deference if it met Mead standards of formality. See Coeur Alaska, Inc. v. Se. Alaska Conservation Council, 129 S.Ct. 2458, 2473 (2009) ("The Memorandum, though not subject to sufficiently formal procedures to merit Chevron deference, is entitled to a measure of deference because it interprets the agencies' own regulatory scheme." (citations omitted)).

${ }^{187}$ The Court may have answered this question in the affirmative. Merrill and Hickman state that the issue is resolved with regard to the Board of Immigration Appeals "but not more generally." Merrill \& Hickman, supra note 2, at 850. The general question seems to have been answered at least in dicta in Mead, which stated that in order to qualify for Chevron deference, an interpretation must have been rendered in a congressionally authorized "process of rulemaking or adjudication." United States v. Mead Corp., 533 U.S. 218, 229 (2001). Merrill and Hickman's article was published while Mead was pending at the Supreme Court.

${ }^{188}$ To Merrill and Hickman's questions, I would add another: Assuming rules issued without notice and comment do not receive Chevron deference, if an agency gratuitously provides notice and comment for an exempt rule, is the rule then eligible for Chevron deference?

${ }^{189}$ Merrill \& Hickman, supra note 2, at 851. Cass Sunstein has argued against Chevron deference for agency decisions concerning their own jurisdiction on the ground that "Congress would be unlikely to want agencies to have the authority to decide on the extent of their own powers." Cass R. Sunstein, Law and Administration After Chevron, 90 CoLUM. L. REv. 2071, 2099 (1990). Michael Herz also has an excellent discussion of this issue. See Herz, supra note 85, at 193-203.

${ }^{190}$ See Dole v. United Steelworkers, 494 U.S. 26, $43-44$ (1990) (White, J., dissenting) (arguing that the issue had been resolved in prior cases in which the Court had applied Chevron to agency statutory decisions affecting their jurisdiction). But see Merrill \& Hickman, supra note 2, at 844 n.54 (concluding that whether there is a jurisdictional exception to Chevron deference is unresolved).
} 
as Justice White stated in a concurring opinion, that the Court has applied Chevron deference to interpretations that affect an agency's jurisdiction, it is also correct that the Court has not explicitly stated that jurisdictional interpretations are subject to Chevron. Thus, the uncertainty identified by Merrill and Hickman persists over the issue in the lower courts. ${ }^{191}$ What makes this issue even more problematic is that even if the Court was sympathetic to the argument that jurisdictional interpretations should not be afforded Chevron deference, there may be "no discernible line between an agency's exceeding its authority and an agency's exceeding authorized application of its authority. To exceed authorized application is to exceed authority." 192

It is not necessarily fatal to the desirability of a precedent that its meaning and application must be developed in subsequent decisions, but it ought to count as a negative when a precedent requires numerous complex decisions simply to determine its scope. These problems with Chevron are especially intolerable because the Chevron doctrine is a framework for decision making and not a substantive doctrine. The Court's approval of the bubble concept for regulating stationary sources of air pollution has turned out to be the least important aspect of the Chevron decision as a precedent. Rather, the decision, at least as understood later, established a framework for judicial review. Many substantive doctrines need years and several cases to work out. The same should not be true of a standard of judicial review or similar decisionmaking framework. These should be ready to go, simple to apply, and relatively stable unless and until the Court decides to make a change. ${ }^{193}$

Chevron Step Zero is thus problematic for reasons beyond guilt by association with Chevron. As the Court has constructed it, it has made a

${ }^{191}$ Merrill \& Hickman, supra note 2, at 844 n.54. The Third Circuit believes the issue was resolved long ago by the Supreme Court: "The Supreme Court has also held that an agency's view of its own statutory jurisdiction may be entitled to deference under Chevron.” Air Courier Conference of Am./Int'l Comm. v. U.S. Postal Serv., 959 F.2d 1213, 1223 (3d Cir. 1992) (citations omitted). However, more recently, Judge Prost of the Federal Circuit wrote, "[A]n agency's determination of the scope of its own authority is not entitled to Chevron deference." Tafas v. Doll, 559 F.3d 1345, 1353 (Fed. Cir. 2009). At the moment, the D.C. Circuit supports the Third Circuit, although its position has shifted. Conn. Dep't of Pub. Util. Control v. FERC, 569 F.3d 477, 481 (D.C. Cir. 2009) ("We afford Chevron deference to the Commission's assertion of jurisdiction.”). For more coverage of this issue, including citations to numerous articles on the subject, see Bressman, Mead, supra note 181, at 147273; Nathan Alexander Sales \& Jonathan H. Adler, The Rest Is Silence: Chevron Deference, Agency Jurisdiction, and Statutory Silences, 2009 U. ILL. L. REV. 1497, 1503-07.

${ }^{192}$ Miss. Power \& Light Co. v. Mississippi ex rel. Moore, 487 U.S. 354, 381 (1988) (Scalia, J., concurring).

${ }^{193}$ Consider, on the one hand, the standard for granting summary judgment. Although the Court has made changes in that standard, the framework itself was relatively clear and stable until the Court decided to make a change. E.g., Celotex Corp. v. Catrett, 477 U.S. 317, 322-24 (1986). On the other hand, consider that one of the reasons for changing the procedure for determining qualified immunity cases was that lower courts had resisted the prior standard and had found it necessary to create numerous exceptions to the process. See Pearson v. Callahan, 129 S. Ct. 808, 817 (2009). 
controversial and complicated inquiry even more so, without any reason to believe that it improves the process of judicial review or results in better agency or judicial decision making. It is the bathwater that ought to be thrown out along with Chevron. The lack of any clear rule concerning when Chevron applies provides, in itself, a powerful argument for abandoning the Chevron framework altogether. ${ }^{194}$

\section{The Failure of Chevron to Increase Deference to Agencies}

The most striking objective measure of the failure of Chevron is that it does not appear to have succeeded in substantially increasing the level of deference to agency statutory interpretation. The studies that have been done show that immediately after the Chevron decision, the rate of affirmance of agency interpretations rose substantially, especially at the court of appeals level, but then in subsequent years it has settled back to a rate that is very close to where it was before Chevron. ${ }^{195}$ That Chevron has not had much, if any, effect at the Supreme Court level should not be surprising in light of one study's finding that Chevron is cited in only about one-third of the cases in which it is potentially relevant. ${ }^{196}$ Perhaps somewhat surprisingly, the study found that approval of an agency interpretation is less likely in cases in which Chevron is cited. This is probably because the Court often cites Chevron Step One's statement that "[i]f the intent of Congress is clear, that is the end of the matter.", 197

It is important that the study considers deference in the lower courts, because a possible defense of Chevron is that while it may have failed at the Supreme Court level, it has served its purposes well at the lower courts. This would be true if the rate of deference to agencies was substantially higher post-Chevron in the lower courts and also if decision making appears to have become much simpler at the lower court level. There is, however, no good evidence that either of these possibilities is true,

${ }^{194}$ As noted above, Justice Stevens has argued that Chevron does not apply to "pure question[s] of statutory construction" because, in his view, such questions are for the courts to decide. See discussion supra notes 156-58 and accompanying text. This basis for not applying Chevron is different from the issues dealt with by the Mead standard but it is related in the sense that Justice Stevens must be proceeding from the premise that Congress has not delegated to agencies the authority to resolve pure questions of statutory interpretation.

${ }^{195}$ See Orin S. Kerr, Shedding Light on Chevron: An Empirical Study of the Chevron Doctrine in the U.S. Courts of Appeals, 15 YALE J. ON REG. 1, 32 (1998) (finding an increase of regulations upheld under Chevron from 58\% one year after the Chevron decision, to $82 \%$ two to four years after Chevron, and then decreasing to $72 \%$ ten years after the Chevron decision); Thomas J. Miles \& Cass R. Sunstein, Do Judges Make Regulatory Policy? An Empirical Investigation of Chevron, 73 U. CHI. L. REv. 823, 849 (2006) (noting that the "average validation rate of the circuit judges in Chevron cases . . . is roughly similar to that of the Supreme Court [J]ustices"); Peter H. Schuck \& E. Donald Elliott, To the Chevron Station: An Empirical Study of Federal Administrative Law, 1990 DuKE L.J. 984, 1031, 1039 (finding an affirmance rate of $70.9 \%$ in 1984 , peaking at $81.3 \%$ in 1986 , and decreasing to $75.5 \%$ in 1988).

${ }^{196}$ Eskridge \& Baer, supra note 2, at 1121

${ }^{197}$ Chevron U.S.A., Inc. v. NRDC, 467 U.S. 837, 842 (1984). 
although they do merit more study. Schuck and Elliot's study indicates that after an initial increase, agency affirmance rates in the lower courts settled back close to pre-Chevron levels. ${ }^{198}$ While it is beyond the scope of this Article to engage in a detailed study of lower court applications of Chevron, a glance at recent decisions of the D.C. Circuit reveals that application of Chevron in that circuit looks similar to its application in the Supreme Court, producing lengthy, complicated, and contentious opinions. ${ }^{199}$ There is thus no reason to believe that Chevron has been more successful in the lower courts than at the Supreme Court.

In a recent and exhaustive study of Chevron, Eskridge and Baer found that Chevron is cited in only a small minority of Supreme Court cases in which it is, on its terms, relevant. ${ }^{200}$ They report that in 1014 cases involving agency interpretation, the Chevron two-step process was cited in $8.3 \%$ of the cases. ${ }^{201}$ In about $40 \%$ of the cases, some other form of deference was applied. ${ }^{202}$ And in more than half of the cases, 53.6\% to be exact, no deference regime was applied. ${ }^{203}$ In other words, as Eskridge and Baer conclude, in more than half of the post-Chevron cases in which the Supreme Court reviewed an agency interpretation, the Court applied what the authors term ' $[t]$ he old 'independent judgment of judges' approach that predated the modern administrative state." ${ }^{204}$ In addition, the authors report that more than $70 \%$ of the cases were decided with either no deference or a slightly deferential "consultative deference" regime, ${ }^{205}$ which means that in the vast majority of cases of review of agency

198 Schuck \& Elliott, supra note 195, at 1039.

${ }^{199}$ See, e.g., Sec'y of Labor v. Nat'l Cement Co. of Cal., 573 F.3d 788, 792-93 (D.C. Cir. 2009); Novelty, Inc. v. DEA, 571 F.3d 1176, 1187 (D.C. Cir. 2009) (Tatel, J., concurring); FedEx Home Delivery v. NLRB, 563 F.3d 492, 502 (D.C. Cir. 2009). Many of the D.C. Circuit decisions cite Chevron but then appear to engage in traditional statutory construction, enveloped perhaps in a false veneer of deference.

${ }^{200}$ Eskridge \& Baer, supra note 2, at 1121. My own casual reading of Supreme Court decisions is consistent with this finding. There are many decisions in which Chevron would seem to be relevant but is not mentioned at all.

${ }^{201}$ Id.

${ }^{202}$ For example, in reviewing interpretations rendered by the NLRB in the course of formal adjudication, the Court apparently often cites Fall River Dyeing \& Finishing Corp. v. NLRB, 482 U.S. 27 (1987), rather than Chevron, on the scope of review. Catherine L. Fisk \& Deborah C. Malamud, The NLRB in Administrative Law Exile: Problems with Its Structure and Function and Suggestions for Reform, 58 DuKE L.J. 2013, 2083 n.263 (2009). For example, Fisk and Malamud note that the Court cited Fall River Dyeing rather than Chevron when it rejected the NLRB's statutory interpretation in NLRB v. Health Care \& Retirement Corp. of America, 511 U.S. 571 (1994). The fact that the Court seems to have developed a unique standard of review for NLRB statutory interpretation decisions after Chevron was already on the books is a strong indication of the weakness of the Chevron framework. The Court's standard of review of Board interpretations is whether the Board's decision is "rational and consistent with the Act” which on its face seems to be less deferential than Chevron. NLRB v. Health Care \& Ret. Corp. of Am., 511 U.S. 571, 576 (1994); see also NLRB v. Ky. River Cmty. Care, Inc., 532 U.S. 706, 725 (2001) (applying the "rational and consistent” standard).

${ }^{203}$ Eskridge \& Baer, supra note 2, at 1121.

${ }^{204}$ Id. at 1121.

${ }^{205} \mathrm{Id}$. 
interpretations, the agencies' views receive little or no deference from the Supreme Court. If Chevron is such an attractive doctrine, you would think that its creator would apply it in more than a small minority of cases. ${ }^{206}$

Traditional tools and plain meaning Chevron should help explain why Chevron does not result in greater deference to agencies. Once the Court opened the Step One inquiry to the broad range of factors that had long been applied in statutory interpretation cases, it made it much easier for a court to find clear congressional intent under Step One and either affirm or reverse the agency without deferring. Justice Scalia's confidence in his ability to discern statutory meaning, and his application of plain meaning Chevron, also places more cases in Step One.

It is necessary, however, to be cautious about using affirmance rates as the measure of the level of deference. There is some evidence that agency interpretation has become more adventurous in light of Chevron as agencies hope that they can get away with more under an extremely deferential standard. ${ }^{207}$ As agency interpretations stray farther from statutory language and legislative intent, the affirmance rate could decline even under a deferential standard. Thus, it may be that although the range of permissible interpretations is wider than it was before Chevron, agencies are more likely to test the limits and suffer rejection of their adventurous interpretations.

In my judgment, both explanations are partly true. It does appear that agencies have become bolder in their interpretations as the Chevron doctrine signals the potential for greater deference. However, the regularity of rejection of agency interpretations under Step One from both the liberal and conservative wings of the Court, and the similarity of Chevron to some elements of pre-Chevron case law, leaves the impression that the more things change, the more they stay the same, and that the Chevron doctrine is not having much of an effect. There is, however, probably greater deference at the court of appeals level. Given circuit judges' lack of control over their dockets, Chevron can be an easy way of deciding numerous cases and thus an effective docket clearing device as potential challengers consider whether pursuing judicial review is likely to produce good results.

Further, the fact that Chevron is not even cited in most cases in which, by its terms, it ought to apply, may say more about the failure of the Supreme Court as an institution than about the failure of the Chevron

${ }^{206}$ There may be a selection problem behind the lack of application of the Chevron framework at the Supreme Court level. The Court tends to select the most complicated and important cases to hear. In that universe of cases, the Chevron framework may be less likely to produce easy answers. Regarding important cases, simple invocation of the Chevron framework to affirm the lower court may not be palatable.

${ }^{207}$ See E. Donald Elliott, Chevron Matters: How the Chevron Doctrine Redefined the Roles of Congress, Courts, and Agencies in Environmental Law, 16 VILL. ENVTL. L.J. 1, 8 (2005). 
doctrine. If Chevron is such an attractive doctrine, however, one would expect that the Court would apply it in all or at least nearly all of the cases in which it provides the governing rule. This provides a strong direct argument for abandoning Chevron. What we now have are parallel lines of cases including multiple Chevrons and non-Chevron review of agency interpretation, with various legal standards that can lead to different results. In other words, the law is in no better shape than it was prior to the passage of the APA and in the pre-Chevron APA period. The only positive effect of Chevron may have been to provide fodder for scholarly analysis. And as this analysis continues, the case for overruling Chevron should get even stronger.

Why has Chevron not led to greater deference to administrative agencies? Without commenting on judicial behavior in other eras, it seems that judges today are not accustomed to deciding cases according to rules when the result of applying the rules would conflict with the judges' own views on how the case should be decided. Whether judges are pursuing their own policy preferences, as Czarnezki's study of judicial review of EPA rules under Chevron suggests, ${ }^{208}$ or pursuing what they see as the correct legal result based on Congress's intent, courts today seem unable or unwilling to sacrifice correctness in each case in favor of the advantages of clear rules. The explicit disavowal in Mead of any rule governing the applicability of Chevron and the development of multiple versions of Chevron Step One are but two illustrations of the tendency in current law to eschew inflexible rules that might stand in the way of judges' satisfaction with the outcome in each case.

\section{How Many Steps?}

The final problem with Chevron in application discussed here is that even after twenty-five years, disagreement persists over the basic question of how many steps the Chevron doctrine contains. The conventional wisdom is that there are two steps, one in which the reviewing court decides whether Congress's intent is clear, and a second in which, after finding no clear congressional intent, the court determines whether the agency's interpretation is permissible, reasonable, or manifestly contrary to the statute. If we consider the inquiry into the scope of Chevron as Step Zero, then Chevron may have three steps. Further, it has been argued that the reviewing court should also apply the arbitrary, capricious standard to the permissible or reasonable interpretation, adding a third or fourth step, depending on when or how you are counting. ${ }^{209}$ This was how review of

\footnotetext{
${ }^{208}$ Czarnezki, supra note 183, at 770.

${ }^{209}$ In 1988, the D.C. Circuit, in an opinion by Judge Harry Edwards, a former administrative law professor, after concluding that the agency's interpretation was permissible under Chevron Step Two,
} 
statutory issues had been characterized by the Supreme Court in some preChevron opinions. This approach has apparently been followed in many decisions in the courts of appeals, ${ }^{210}$ although the Supreme Court has never explicitly endorsed it or actually engaged in arbitrary, capricious review of a permissible statutory interpretation. ${ }^{211}$

Recently, an argument broke out among administrative law scholars over whether Chevron has one step or two. Matt Stephenson and Adrian Vermeule argued that Chevron has only one step. ${ }^{212}$ They argued that the only question is whether the agency's interpretation is permissible because if Congress's intent is clear, then only an interpretation consistent with that clear intent can be permissible. They argued that the two-step characterization of Chevron has caused needless confusion and should be jettisoned. Ken Bamberger and Peter Strauss responded that Stephenson and Vermeule are incorrect. ${ }^{213}$ In their view, Step One of Chevron is a pinpoint inquiry into whether Congress has compelled resolution of the question at issue either with or against the agency's interpretation, while Step Two allows the Court to assess the reasonableness of an interpretation arrived at free from congressional compulsion. Bamberger and Strauss did not agree that this separation of the inquiry is confusing and found it perfectly sensible. ${ }^{214}$

If there are ever winners in a scholarly debate, Stephenson and Vermeule seem to have had the better of this argument, at least partially. In a very recent decision, Justice Scalia's majority opinion collapsed the inquiry under Chevron into one step, stating that the agency view "governs if it is a reasonable interpretation of the statute."215 In response to the dissent's complaint that Justice Scalia's opinion does not follow Chevron, the opinion states:

The dissent finds it "puzzling" that we invoke this proposition (that a reasonable agency interpretation prevails)

applied arbitrary, capricious review to test the wisdom of the choice among permissible interpretations. Int'l Bhd. of Elec. Workers v. ICC, 862 F.2d 330, 338 (D.C. Cir. 1988).

${ }^{210}$ See, e.g., N.Y. Pub. Interest Research Group, Inc. v. Johnson, 427 F.3d 172, 179 (2d Cir. 2005) (applying Chevron and the arbitrary, capricious test).

${ }^{211}$ The Court recited the arbitrary, capricious standard in Chevron itself, and it has continued to do so in later cases, but it has never actually engaged in arbitrary, capricious review of a statutory construction under Chevron-i.e., it has never asked whether the agency considered all relevant factors or made an error in judgment in its choice of permissible or reasonable construction. See Household Credit Servs., Inc. v. Pfennig, 541 U.S. 232, 242 (2004) (stating the "arbitrary or capricious" standard but not applying it in instant case); Chevron U.S.A., Inc. v. NRDC, 467 U.S. 837, 843-44 (1984) (same).

${ }^{212}$ Mathew C. Stephenson \& Adrian Vermeule, Chevron Has Only One Step, 95 VA. L. REV. 597, 597 (2009).

${ }^{213}$ Kenneth A. Bamberger \& Peter L. Strauss, Chevron’s Two Steps, 95 VA. L. ReV. 611, 624-25 (2009).

${ }^{214} \mathrm{Id}$.

${ }^{215}$ Entergy Corp. v. Riverkeeper, Inc., 129 S. Ct. 1498, 1500 (2009) (citations omitted). 
at the "outset," omitting the supposedly prior inquiry of "whether Congress has directly spoken to the precise question at issue.” But surely if Congress has directly spoken to an issue then any agency interpretation contradicting what Congress has said would be unreasonable. ${ }^{216}$

This may signal that the Supreme Court may, in the future, omit the Chevron two-step process in favor of a single inquiry into the reasonableness of the agency's interpretation. It did so again in a decision issued a week later, ${ }^{217}$ but on the same day as the first one-step opinion was issued, in an opinion by Justice Kennedy, the Court applied the more familiar two-step version of Chevron, providing at least a consolation prize to Bamberger and Strauss. ${ }^{218}$

Unfortunately, Stephenson and Vermeule threw a spanner into the works when they suggested that permissible or reasonable interpretations are still subject to "State Farm" review for reasoned decision making under the APA's judicial review provision. ${ }^{219}$ As noted above, the Supreme Court has not subjected interpretations approved under Chevron Step Two to further review under the arbitrary, capricious test. By arguing for separate (non-Chevron) arbitrary, capricious review, Stephenson and Vermeule were arguing against collapsing Chevron Step Two with arbitrary, capricious review since they had previously argued that Steps One and Two should be collapsed into a single "permissible construction" inquiry. ${ }^{220}$ Perhaps they are correct that Chevron Step Two is about statutory meaning and not about the wisdom of the agency's policy choice, but that the wisdom of the agency's policy choice should be explored in a separate arbitrary, capricious step. ${ }^{221}$ However, although the D.C. Circuit has conducted arbitrary, capricious review as a separate inquiry, ${ }^{222}$ when the Supreme Court has mentioned arbitrary, capricious review in Chevron opinions, it has always included it in Step Two, not as an additional inquiry. It has also, however, rejected separate arbitrary, capricious

\footnotetext{
${ }^{217}$ The Court employed the one-step formulation again in Cuomo v. Clearing House Ass'n, 129 S. Ct. 2710, 2715 (2009).

${ }^{218}$ Coeur Alaska, Inc. v. Se. Alaska Conservation Council, 129 S. Ct. 2458, 2471-72 (2009). The number of steps in Chevron in any given case may turn out to depend on who writes the Court's opinion.

${ }^{219}$ By "State Farm" review, they meant arbitrary, capricious review of policy.

${ }^{220}$ Stephenson \& Vermeule, supra note 212, at 599.

${ }^{221}$ This conclusion may be correct under the current understanding of Chevron, but it is contrary to the pre-Chevron understanding of review of agency interpretations for reasonableness. See discussion supra, notes 42-52 and accompanying text.

${ }^{222}$ See supra note 209 and accompanying text.
} at 842 ).

${ }^{216}$ Id. at 1505 n.4 (quoting dissenting opinion of Justice Stevens and quoting Chevron, 467 U.S. 
scrutiny of interpretive choices. ${ }^{223}$ Thus, Stephenson and Vermeule's argument that permissible constructions are subject to "State Farm" review is speculative, at best, at least as far as the Supreme Court is concerned.

This brings us back to the complete mess that the Supreme Court has made of the relationship between Chevron and arbitrary, capricious review. As discussed above, whether a permissible or reasonable interpretation can still be arbitrary, capricious, or an abuse of discretion is a puzzling question. If an agency interpretation is truly interpretive, and it is within the range of interpretations contemplated by Congress, it is difficult to see how it can be permissible or reasonable but also arbitrary, capricious, or an abuse of discretion. Agency action is reviewed for consistency with Congress's instructions. Once such consistency is established, it seems impossible for the agency action to be incorrect. One D.C. Circuit opinion argued against applying traditional arbitrary, capricious review to agency interpretations for similar reasons:

[M]uch of the "arbitrary and capricious" style analysis concerned with reasoned agency decisionmaking that is articulated in the Overton Park and Airbags line of cases cannot be applied directly to the question of whether an agency's interpretation of a statute is "contrary to law." It would be inappropriate, therefore, to import wholesale that body of law and apply it in a conceptually distinct arena. ${ }^{224}$

The court argued that an agency interpretation should be upheld if the agency gives a reasoned explanation for it. However, if an agency choice of interpretation is arbitrary, capricious or an abuse of discretion, it is difficult to see how it can at the same time be consistent with Congress's intent. This assumes that Congress writes statutes that are arbitrary or capricious. This is one of the numerous complications that have arisen under Chevron that would not exist if the Chevron doctrine was abandoned.

Chevron thus has anywhere from one to four steps depending on what and how one counts. After twenty-five years, we should expect more clarity regarding the application of a framework doctrine like Chevron.

\section{The Costs of Chevron}

The two remaining reasons for overruling Chevron involve the costs

\footnotetext{
${ }^{223}$ In one opinion, the Court treated this issue as follows: "The incumbents make the additional argument that it was arbitrary or capricious for the FCC to reject historical costs, but this is simply a restatement of the argument that the FCC was unreasonable in interpreting § 252(d)(1) to foreclose the use of historical cost in ratesetting, which we have already addressed[.]” Verizon Commc'ns Inc. v. FCC, 535 U.S. 467, 527 n.38 (2002) (citations omitted). The Court thus seems to equate reasonable or permissible interpretation with surviving review under the arbitrary, capricious test.

${ }^{224}$ Continental Air Lines v. Dep’t of Transp., 843 F.2d 1444, 1452 (D.C. Cir. 1988).
} 
and benefits of the Chevron doctrine. These are obviously closely linked to the high degree of uncertainty the doctrine has created and thus require less discussion than the others to understand. These reasons are: first, that the uncertainty discussed above surrounding the application of Chevron and when it applies has forced courts and litigants to expend inordinate resources on arguing over the Chevron doctrine, and second, that Chevron causes two conflicting tendencies in agency behavior and a related sort of irresponsible judicial behavior. If (perhaps overconfident) agencies view Chevron as embodying extreme deference, they may disregard congressional intent and push their own policy views against a discernible, but not absolutely clear, congressional intent. Reviewing courts likewise can brush off serious challenges to agency decisions based in congressional intent by invoking Chevron. Pointing in the opposite direction, agencies with a more realistic understanding of Chevron may be extra-cautious because they cannot predict whether their interpretive decisions will be greeted with deference or suspicion on judicial review.

The first point should be obvious. This Article has only scratched the surface of the complexities and uncertainties created by the Chevron doctrine. There is extensive litigation, especially in the Supreme Court and courts of appeals, concerning the various issues that arise under Chevron and there are hundreds of law review articles teasing out dozens of issues and creatively raising problems that no one may have anticipated. It is not necessarily negative that a legal doctrine needs to be worked out over time in a case by case manner, but there does not seem to be much value doing so regarding Chevron. Administrative agencies were not in crisis when their interpretive decisions were reviewed under pre-Chevron practices. There are much simpler doctrines that could be used to review agency legal interpretations that would not require extensive litigation to work out all the ins and outs and twists and turns of the doctrine. The Chevron doctrine distracts attention from the real issues in the case, namely the substance of the agency's action and the statutes and regulations under which the agency acted. Had the Chevron doctrine succeeded in simplifying judicial review or creating substantially more deference to agency interpretations, that may have saved enough resources and discouraged enough litigation to make the costs of administering Chevron worthwhile. Although I have no way of verifying this, based on all of the ink that has been spilled over whether and how Chevron applies in a particular case, I strongly suspect that the Chevron doctrine has resulted in a net waste of resources for parties, lawyers, and judges.

It would be different if Chevron served an important substantive goal such as observing the separation of powers or preventing judges from imposing their own will over that of the legislature or agencies. But as Chevron has evolved, there is good reason to believe that the opposite has occurred. Chevron has not accomplished the goal of constraining judicial 
decision making. Assuming that the Chevron Court was correct that ordinary judicial review allows judges to impose their policy preferences, the multiple versions of Step One allow judges to consider any factor they considered before Chevron. And if for some reason Chevron does not work, the court can deem the case extraordinary or find a reason why Chevron does not apply under Step Zero. In short, Chevron has not accomplished its primary substantive goal of preventing unaccountable judges from imposing their preferences over those of the agencies or Congress.

In fact, Chevron has provided courts with a mechanism for reducing their accountability by hiding their decisions approving agency action behind a veneer of deference. In a close case in which the judges agree with a controversial agency action, rather than approve the action on the merits, the court can employ a deferential version of Chevron and plead constraint. In short, careful, considered judgment by judges is no longer necessary to judicial review of agency statutory interpretation.

Chevron also has costs in terms of accountability, democracy, and the quality of agency decision making. As discussed above, accountability of agencies through the President may exist, but it is far from a complete answer to the democracy deficit caused by increased agency discretion. If it is true that judicial review, at least in some circumstances, enforces Congress's intent against an agency pursuing the administration's priorities, then in those circumstances judicial review enhances accountability and democracy by strengthening Congress's hand against the agencies. Of course, I cannot demonstrate definitively that this possibility outweighs the tendency of judges to assert their own views, but it is my impression that in many cases reviewing courts at least appear to be trying in good faith to act in accord with congressional intent.

As E. Donald Elliott has argued, Chevron deference may inspire agencies to adopt adventurous interpretations, far from any good faith reading of Congress's intent. He found this sort of behavior to be part of the culture in the post-Chevron EPA. ${ }^{225}$ Not only might this increase the accountability and democracy problems associated with the administrative state, it could lead to poor decisions given the relatively lower level of deliberation necessary to make law in an agency as compared with Congress. Of course, Congress is far from a perfect institution, and Congress has enacted its share of bad ideas, but there is an obvious advantage to the requirements of numerosity of congressional membership, and bicameralism and presentment that are required for the enactment of a statute, as compared with adoption by a single agency head, perhaps with approval from the Office of Information and Regulatory Affairs as part of

${ }^{225}$ Elliott, supra note 207, at 3. 
centralized review. There is oversight of agency action by Congress and the President, but often the most effective oversight device has been judicial review.

The final reason for overruling Chevron is that, based on the case law and scholarly commentary, it does not appear likely that the difficulties in understanding and applying Chevron will be resolved in the near future. Perhaps Chevron would be worth preserving if it appeared that it was about to become crystallized into a coherent, workable rule. This does not, however, seem likely. One reason for this is that the scholarly commentary is in just as much, if not even more, disarray than the case law. Chevron is unlikely to become a simple framework for deciding cases. To a certain extent, this follows from much of what appears above. To the mass of criticism of Chevron, here I add two factors: first, that there is no stable coalition on the Court for a particular version of the Chevron doctrine, and second, that the scholarly commentary does not exhibit signs of coming to a consensus concerning the proper understanding and application of the Chevron doctrine.

In cases decided under the Chevron framework, the Supreme Court tends to split along familiar conservative-liberal lines concerning the merits of the case at hand rather than on lines about the appropriate level of deference. $^{226}$ In other words, the liberals on the Court tend to vote to

${ }^{226}$ To illustrate this point, I looked at all of the Supreme Court decisions from the 2005 through 2008 Terms in which Chevron was applied by the majority or argued in a dissent. I found a relatively consistent voting pattern with the Court splitting along familiar liberal/conservative lines most of the time. I placed Justices Stevens, Souter, Ginsburg, and Breyer in the liberal wing; Chief Justice Roberts and Justices Scalia, Thomas, and Alito (2006-08 Terms) in the conservative wing; and Justices Kennedy and O'Connor (2005 Term) as swing votes. Of the seventeen cases in my sample, seven were 5-4 decisions. Two were decided by a conservative majority deferring to the agency. Entergy Corp. v. Riverkeeper, Inc., 129 S. Ct. 1498 (2009); Nat'l Ass'n of Home Builders v. Defenders of Wildlife, 551 U.S. 644 (2007). Two were decided by a conservative majority not deferring to the agency. Ledbetter v. Goodyear Tire \& Rubber Co., 550 U.S. 618 (2007); Rapanos v. United States, 547 U.S. 715 (2006). One was decided by a liberal majority deferring to the agency, although in that case Justice Alito joined the liberal wing and Justice Souter dissented against deferring to the agency together with the rest of the conservative wing. Zuni Pub. Sch. Dist. No. 89 v. Dep’t of Educ., 550 U.S. 81 (2007). Two were decided by a liberal majority not deferring to the agency, although in one of those two decisions, Cuomo v. Clearing House Association, 129 S. Ct. 2710 (2009), Justice Scalia was in the majority and Justice Kennedy dissented in favor of deference together with Chief Justice Roberts and Justices Thomas and Alito. See also Dada v. Mukasey, 128 S. Ct. 2307 (2008). There was also one 5-3 liberal decision in favor of deference again with Justice Alito in the majority and this time with Justice Stevens joining two conservatives in dissent. Watters v. Wachovia Bank, N.A., 550 U.S. 1 (2007). Justice Thomas did not participate. There were three 6-3 decisions, two with the conservatives plus Justice Breyer not deferring, Coeur Alaska, Inc. v. Southeast Alaska Conservation Council, 129 S. Ct. 2458 (2009), and Carcieri v. Salazar, 129 S. Ct. 1058 (2009), and one with the liberals and both swing Justices not deferring in a 2005 Term case before Justice Alito replaced Justice O'Connor. Gonzales v. Oregon, 546 U.S. 243 (2006). There were four 7-2 decisions. I counted them as liberal or conservative based on the identity of the dissenters. In two of these decisions, liberals deferred to agencies with Justices Scalia and Thomas in dissent. Fed. Exp. Corp. v. Holowecki, 128 S. Ct. 1147 (2008); Global Crossing Telecomms., Inc. v. Metrophones Telecomms., Inc., 550 U.S. 45 (2007). In the other two decisions, the conservatives did not defer, with Justices Stevens and Souter dissenting in one, Morgan Stanley Capital Group Inc. v. Public Utility District No. 1, 128 S. Ct. 2733 (2008), and Justices Stevens 
uphold what would be considered liberal agency outcomes and to reject conservative agency outcomes while the conservatives tend to do the opposite. The wild cards tend to be Justices Scalia, Alito, and Chief Justice Roberts. Justice Scalia has voted quite frequently against deferring to an agency, ${ }^{227}$ usually grouped together with other Court conservatives, but he also voted with the liberals against deferring in at least one decision in the last four terms. ${ }^{228}$ This is consistent with Justice Scalia's selfassessment that he is more likely than other judges to find statutory language clear. While Justice Alito is generally part of the Court's conservative wing, he has voted four times with the liberals in favor of deferring to an agency, ${ }^{229}$ while Chief Justice Roberts voted twice with the liberals in favor of deferring, indicating that Justices Alito and Roberts may be more committed to the principle of Chevron deference than their colleagues.

The voting patterns illustrate that there is no predictable divide on Chevron. While the pro-deference view has been associated with the Court's conservatives and the less deferential, traditional view has been associated with the Court's liberals, both of these associations are inaccurate. In case after case, the Court's decision breaks down along liberal-conservative lines on the merits without regard to which side is congruent with deference to the agency. In almost every divided opinion in recent years in which Chevron has been invoked, the voting pattern reflects the liberal-conservative divide on the merits of the case rather than on the proper application of Chevron. Thus, even if one side took control of the Supreme Court through several appointments, it is unlikely that the Court would settle on a consistent application of Chevron. Rather, the Court would likely become consistent with regard to the political orientation of its decisions, and would defer, or not, based on whether the administration's political orientation continued to be the same.

That is not to say that Chevron is not discussed in the Court's opinions.

and Breyer dissenting in the other, Negusie v. Holder, 129 S. Ct. 1159 (2009). There were two unanimous decisions in favor of deferring to agencies: United States v. Eurodif S.A., 129 S. Ct. 878 (2009) and Long Island Care at Home, Ltd. v. Coke, 551 U.S. 158 (2007). In summary, counting 7-2 decisions as attributable to the dominant group in the majority (as determined by the identity of dissenters who always were from one wing or the other) there were six decisions by the conservative wing against deference, three decisions by the liberal wing against deference, two decisions by the conservative wing in favor of deference and four decisions by the liberal wing in favor of deference. I recognize that this is not a scientific survey, but nevertheless I believe that it helps illustrate that for whatever reason, disparate views about Chevron do not seem to explain voting patterns on the Court.

${ }^{227}$ Because he voted against deference in all six of the conservative decisions that went against the agency, with the liberals in one of their decisions that went against the agency, and dissented against the liberals in all four of the cases in which they deferred, Justice Scalia's eleven votes against deference was the highest number of votes among the Justices against deference. Justice Alito voted most often in favor of deference with ten votes in favor of deference. See supra note 226 for Justice Alito's voting record.

${ }^{228}$ Cuomo v. Clearing House Ass'n, 129 S. Ct. 2710 (2009).

${ }^{229}$ Zuni, 550 U.S. 81; Watters, 550 U.S. 1. 
To the contrary, in many of the opinions the proper application of Chevron is a matter of dispute between the majority and the dissent. If the majority is affirming the agency's decision, the dissent will complain that the majority is being too deferential, perhaps because the issue is one of law for a court to decide or because the agency's decision is contrary to Congress's intent or the plain meaning of the statutory language. If the majority is rejecting the agency's decision, the dissent will complain that the majority has failed to follow Chevron's deference requirement. The conservatives and liberals move from one side of the Chevron fence to the other. The only factor that is relatively consistent is the political alignment between the blocs and the substantive issues in the case. Chevron deference does not appear to be determinative to anyone, except perhaps Justice Alito and to a lesser extent Chief Justice Roberts, who more often than others cross ideological lines and defer.

The scholarship on Chevron is also indicative of the unlikelihood that a consensus, simple framework is likely to soon emerge from Chevron doctrine. The scholarly commentary on Chevron, even after twenty-five years, does not exhibit anything approaching a consensus on many key issues concerning Chevron. The commentary after Chevron was decidedly negative, reminiscent of the even stronger negative reaction to President Reagan's assertion of authority, in Executive Order 12,291, to review agency rules. ${ }^{230}$ Although the commentary has turned somewhat more favorable over time, the lack of consensus and clarity in the commentary illustrates that Chevron is unlikely in the near future to become a clear, workable standard for judicial review of agency statutory construction.

The scholarship on Chevron and all of its twists and turns is too voluminous to summarize or describe in any detail. The decision has been cited in thousands of law review articles. ${ }^{231}$ Each major Chevron development provokes a new flurry of scholarship along the same lines, most recently regarding Brand $X$ 's holding regarding agency flexibility ${ }^{232}$ and Mead's elaboration of Chevron Step Zero. ${ }^{233}$ Even decades after the decision, scholarly articles continue to offer novel justifications for and understandings of the Chevron doctrine, illustrating the unlikelihood that a (1988)

${ }^{230}$ Exec. Order No. 12,291, 3 C.F.R. 127 (1982), reprinted in 5 U.S.C. § 601 app. at 473-76

${ }^{231}$ See supra note 6 (listing the number of citations to the Chevron decision in Westlaw's database of law review articles).

${ }^{232}$ See Jerry Ellig \& Alastair Walling, Regulatory Status of VOIP in the Post-Brand X World, 23 SANTA Clara Computer \& High Tech. L.J. 89, 91 (2006); Gifford, supra note 64, at 785-86; Harper, supra note 54, at 192-93; Jonathan Masur, Judicial Deference and the Credibility of Agency Commitments, 60 VAND. L. REV. 1021, 1024-25 (2007).

${ }^{233}$ See Kenneth A. Bamberger, Normative Canons in the Review of Administrative Policymaking, 118 YALE L.J. 64, 75 (2008); Bressman, Chevron's Mistake, supra note 64; Levin, supra note 107, at 1253-56; Randolph J. May, Defining Deference Down: Independent Agencies and Chevron Deference, 58 ADMIN. L. REV. 429, 429-432 (2006). 
strong scholarly consensus might support the doctrine and help domesticate it. ${ }^{234}$ Because the Chevron doctrine is contrary to accepted principles and yet has strong appeal to some, some of the scholarship contains creative justifications for or characterizations of Chevron in attempts to rehabilitate the doctrine. The recent scholarly debate, discussed above, concerning whether Chevron really has two steps or only one step is indicative of the degree of diversity of opinions and approaches regarding Chevron. ${ }^{235}$

If there were a strong scholarly consensus on Chevron, as to either its theoretical basis or its application, perhaps over time it could be expected that, as the numerous issues underlying it were resolved, the doctrine would become easier to apply and less subject to dispute in litigation. However, just as judicial consensus appears unlikely, scholarly consensus does not seem likely to emerge anytime soon.

\section{Why It WOULD Be ACCEPTABLE TO OVERRULE CHEVRON}

As explained above, there are strong reasons for abandoning the Chevron doctrine and replacing it with a simpler doctrine that is more consistent with the values underlying administrative law. This section explains why Chevron meets the standards that the Supreme Court has applied to the question of whether it is appropriate, in light of the tradition of stare decisis, to overrule a particular precedent.

In a recent decision, Pearson v. Callahan, ${ }^{236}$ the Supreme Court specified three issues that are relevant to whether overruling a decision is consistent with stare decisis principles. The Court stated, "Revisiting precedent is particularly appropriate where . . . a departure would not upset expectations, the precedent consists of a judge-made rule that was recently adopted to improve the operation of the courts, and experience has pointed

\footnotetext{
${ }^{234}$ Evan Criddle recently noted that scholars have offered various theoretical justifications for Chevron, which has affected the development of the doctrine itself. Criddle, supra note 63, at 12991300. Examples from a small tip of the huge iceberg of relatively recent scholarship about the foundations of the Chevron doctrine include: Bamberger \& Strauss, supra note 213; Curtis A. Bradley, Chevron Deference and Foreign Affairs, 86 VA. L. REV. 649 (2000); Bressman, Chevron's Mistake supra note 64; Gersen \& Vermeule, supra note 64; Gifford, supra note 64; Harper, supra note 54; Richard J. Pierce, Jr., Chevron Should Not Be Converted into a Voting Rule: A Response to Gersen and Vermeule's Proposal, 116 YALE L.J. POCKET PART 248 (2007), available at http://www.yalelawjournal.org/content/view/98/23/; Matthew C. Stephenson, The Costs of Voting Rule Chevron: A Comment on Gersen and Vermeule's Proposal, 116 YALE L.J. POCKET PART 238 (2007), available at http://www.yalelawjournal.org/content/view/99/23/; Stephenson \& Vermeule, supra note 212.

${ }^{235}$ See supra notes 209-24 and accompanying text.

${ }^{236} 129$ S. Ct. 808, 811 (2009). Pearson overruled the requirement established in Saucier v. Katz, 533 U.S. 194, 200 (2001), that federal courts ruling on qualified immunity first address whether the defendant violated the plaintiff's rights before addressing whether the rights were clearly established enough to overcome the immunity.
} 
up the precedent's shortcomings." 237 The Court also stated two factors counseling hesitation before overruling a precedent. First, precedents in the areas of property and contract rights should not be lightly overruled because of the higher than usual reliance on such precedents, and second, statutory construction precedents should not be lightly overruled because of "the general presumption that legislative changes should be left to Congress." 238

Chevron meets all of the criteria to allow overruling and does not run afoul of either of the factors counseling hesitation. First, overruling Chevron would not upset any legitimate settled expectations. Chevron is not a substantive rule that people have relied on in structuring their affairs. As a rule of judicial review, it is unlikely that Congress actually considers the particulars of the Chevron doctrine when it writes statutes, ${ }^{239}$ and insofar as agencies may react to Chevron with adventurous statutory interpretations, any expectations they may have of getting away with an interpretation that is contrary to congressional intent are not realistic. Further, the application of Chevron is so uncertain that no one could truly rely on it with any substantial confidence.

Second, Chevron is a judge-made rule that, had it functioned properly, would have, at least in part, improved the operation of the courts. It does not fit this criterion perfectly, because twenty-five years is not of the same recent vintage as the rule abandoned in Pearson, and it was developed in part out of concern for separation of powers principles underlying the administrative state. Nevertheless, stare decisis principles should not stand as an obstacle to overruling Chevron. The fact that Chevron has been in existence for twenty-five years is somewhat misleading because new issues and elements keep popping up, such as the Step Zero doctrine which is a much more recent creation. Chevron has not been a settled doctrine for twenty-five years, rather it has been more like a pot that has never quite boiled or cooled. Further, the separation of powers principles underlying Chevron are contested. Some find Chevron itself inconsistent with traditional understandings of the proper distribution of powers in the administrative state. In any case, any likely replacement for Chevron could attend to the separation of powers principles as effectively as Chevron itself, if not more so.

Third, the entire premise of this Article is that experience with

${ }^{237}$ Pearson, 129 S. Ct. at 816.

${ }^{238}$ Id. (quoting State Oil Co. v. Khan, 522 U.S. 3, 20 (1997)).

${ }^{239}$ See Abner J. Mikva, Speech, How Should the Courts Treat Administrative Agencies?, 36 AM. U. L. REv. 1, 7 (1986) ("As Chevron suggests, Congress could provide very detailed statutory directives to the agency [to avoid delegation]. . . . Having served in the Congress, I know that it is far from clear that Congress, as a political body, has either the time or the political will to draft such minute instructions into law.... Even the most delphic legislators simply cannot devise instructions for all future questions of statutory interpretation that will come before an agency.” (footnotes omitted)). 
Chevron over the years has pointed out its shortcomings. If the Article is not correct, then the case for overruling Chevron is not made. In my view, Chevron has failed in just about every possible way and any benefits it provides do not outweigh the costs.

Chevron does not implicate either of the factors counseling hesitation before overruling a precedent. Chevron is not a rule of property or contract law against which transactions or investments have been structured. ${ }^{240}$ Chevron is also not a rule of statutory construction. If anything, Chevron was constructed in disregard of statutory language or even contrary to the language and intent of the APA. In short, principles of stare decisis do not counsel against overruling Chevron.

In fact, the Court's reasoning in Pearson supports overruling Chevron. Pearson overruled the Court's Saucier rule that when deciding on qualified immunity in civil rights cases, a court should first decide the constitutional issue and then go on to determine whether any constitutional right that was violated was clearly established at the time the defendant government official committed the violation. Among the problems identified with the Saucier rule were that applying the rule wasted the parties' and courts' resources, that it was met with resistance from lower courts, that it was contrary to well-established legal traditions, and "[t]he procedure sometimes results in a substantial expenditure of scarce judicial resources on difficult questions that have no effect on the outcome of the case."241 These same criticisms could be leveled at Chevron.

Most notably, the primary source of instability in both the Pearson and Chevron doctrines is identical, namely, inconsistency with bedrock legal principles. For Pearson, the problem with the doctrine it overruled was that it required courts to decide constitutional questions when the decision might not matter to the outcome of the case. This appeared, to many, to be a breach of the fundamental doctrine of constitutional avoidance, that courts should decide constitutional issues only when necessary. ${ }^{242}$ For Chevron, the main problem is that, as it has come down, it seems inconsistent with the tradition of judicial determination of the meaning of statutes. Any doctrine that goes against the tide of fundamental, wellestablished doctrines would seem to be a good candidate for overruling.

\section{CHEVRON'S REPLACEMENT}

The final, and perhaps most difficult, part of this Article is to propose a replacement for the Chevron doctrine. What the Court should do is declare

\footnotetext{
${ }^{240}$ See Pearson, 129 S. Ct. at $816-17$.

${ }^{241} I d$. at 818.

${ }^{242}$ See Thomas Healy, The Rise of Unnecessary Constitutional Rulings, 83 N.C. L. REV. 847, 848-50 (2005) (discussing the recent rise in instances where the Court has reached out to decide constitutional issues even when doing so is not necessary to the outcome of the case).
} 
that Chevron has become unmanageably complicated and that some of its applications are inconsistent with the APA and other governing legal principles. The best result would be for the Court to disavow the Chevron two-step framework and apply the APA's apparent requirement that reviewing courts decide all questions of law raised on judicial review, recognizing that in some statutes, Congress may have prescribed a range of permissible interpretations. ${ }^{243}$ If, however, the Court is unwilling to go so far as to eliminate deference to agency statutory interpretation, then three aspects of the Chevron framework should be explicitly disavowed: first, the "directly spoken to the precise question at issue" version of Step One; second, the suggestion that the "permissible" or "reasonable construction" standard governs review of the wisdom of agency policy; and third, the incredibly pliable Mead standard for determining whether agency statutory interpretation is entitled to deference. ${ }^{244}$

\section{A. Reforms of Chevron}

If the basic two-step Chevron framework is maintained, Step One should be reformed in two different ways. First, the Court should explicitly disavow the narrow version of Step One under which agency interpretation governs unless "Congress has directly spoken to the precise question at issue." ${ }^{245}$ This standard was the most startling element of the Chevron test and has never been accepted as consistent with fundamental principles of the proper judicial role in judicial review of administrative action. The Court should make clear that all agency legal decisions are subject to review for consistency with statutory language and congressional intent, broadly understood under generally accepted principles of statutory interpretation. The only concession the Court should make to the Chevron framework is to acknowledge that sometimes Congress establishes broad statutory limits within which the agency exercises discretion subject to judicial review for straying beyond the statutory bounds of discretion. The reviewing court should explicitly state when this is so, to preserve the agency's future flexibility to adopt a different view of the law in appropriate circumstances.

The permissible or reasonable construction standard in Step Two should be maintained for those instances in which the reviewing court determines that Congress intended to grant the agency discretion to make

${ }^{243}$ Bill Andersen has suggested a legislative reform that is similar to what is suggested here, replacing Chevron deference with an amendment to APA § 706(2) enacting a form of Skidmore deference. See William R. Andersen, Against Chevron: A Modest Proposal, 56 Admin. L. Rev. 957, 964-69 (2004).

${ }^{244}$ While I recommend eliminating all three, in fact, each of these aspects of the Chevron framework operates independently and thus each could be jettisoned separately without regard to whether the others survive.

${ }^{245}$ Chevron U.S.A., Inc. v. NRDC, 467 U.S. 837, 842 (1984). 
legal determinations within a range of possible statutory meanings. This would most clearly be the case when a statute contains language such as "as defined by" the relevant agency. The Court should make it clear, however, that the agency's choice of a permissible or reasonable construction is subject to review under the arbitrary, capricious test. This is a little trickier than it sounds because of the difficulty, discussed above, with the idea that a permissible construction could nonetheless be arbitrary or capricious, given that arbitrary, capricious review centers on whether the agency has considered only the factors made relevant by Congress in the governing statute. In addition to considering only those factors, the agency's decision also has to represent a plausible consideration of those factors, and thus can still be arbitrary or capricious even if all relevant factors have been considered. ${ }^{246}$ This determination should be made under the arbitrary, capricious standard established in Overton Park, State Farm, and their progeny.

Third, the Court should acknowledge that Mead has only made it more difficult for lower courts to figure out when to apply the Chevron framework and is not a sensible understanding of congressional intent visà-vis agency authority. Rather, the Court should apply its less deferential standard of review to all agency statutory interpretations, and should get into Chevron Step Two only when Congress has explicitly delegated legal decisionmaking authority by stating that a statutory term is subject to agency definition $^{247}$ that would be reviewed under Step Two as noted above.

\section{B. Replacements for Chevron}

If the Court were to decide to simply jettison the Chevron framework altogether, in a sense, there would be no need for a replacement. If Chevron was wiped from the books and the Court declared that Chevron and all of its progeny were no longer good law, the law would revert to pre-Chevron practice. Under that practice, in the case of an ambiguous statutory provision, when an agency had the power to make legislative rules, the reviewing court would determine whether the agency had implemented the statutory provision in a reasonable manner with attention to the meaning of the statute, its purpose and history, and the wisdom of its policy choices under the arbitrary, capricious standard. Pre-Chevron, the ultimate answer to the reasonableness question was an issue for the

${ }^{246}$ See Motor Vehicle Mfrs. Ass’n of the U.S. v. State Farm Mut. Auto. Ins. Co., 463 U.S. 29, 43 (1983) (stating one element of review under the arbitrary, capricious standard is that the agency's explanation for its action should not be "so implausible that it could not be ascribed to a difference in view or the product of agency expertise").

${ }^{247}$ See supra note 68 for examples of statutes in which Congress has expressly granted agencies the power to define statutory terms. 
reviewing court, with careful attention to the agency's views and Congress's intent. When an agency was expressly granted power to create law in a gap purposely left in a statute (i.e., where no statute, ambiguous or not, governed) the pre-Chevron Court stated the standard of review as follows: "The regulation at issue in this case is therefore entitled to more than mere deference or weight. It can be set aside only if the Secretary exceeded his statutory authority or if the regulation is 'arbitrary, capricious, an abuse of discretion, or otherwise not in accordance with law." 248 In these cases, the reviewing court would ensure that the agency's interpretation was within the range intended by Congress and would also ensure that the chosen meaning was not arbitrary or capricious as a matter of policy.

These are not really two different standards of review, but rather are the same standard applied to two different situations, one in which there is statutory language against which to judge the agency's action and one in which there is not. When agency action under an ambiguous statute is reviewed, the agency's interpretation is reviewed for consistency with the discernible limits imposed by the ambiguous statute. When an agency acts under an explicit grant of interpretative power, ${ }^{249}$ there is no statutory language against which to judge the agency's action, and the reviewing court must ensure that the agency has not gone beyond the delegation-for example, by defining a term that the statute does not assign to the agency for definition or by defining a term in a way that is beyond limitations imposed elsewhere in governing statutes. ${ }^{250}$ In both situations, the soundness of the agency's interpretive choice is also subject to review under the arbitrary, capricious standard.

The pre-Chevron rules governing judicial review of agency interpretations, if re-adopted, should be unified to make them simpler to apply. The practice regarding review of agency interpretation of ambiguous statutes should not depend on whether the agency has been granted the power to make legislative rules. Rather, whenever an agency interprets an ambiguous statute, whether in a rulemaking, an adjudication, or an informal action, the question on judicial review should be the same: whether, in light of text, purpose, and legislative history, the agency's interpretation is reasonable, and whether its policy meets the arbitrary,

${ }^{248}$ Batterton v. Francis, 432 U.S. 416, 426 (1977) (quoting 5 U.S.C. § 706(2)(A), (C) (1976)) (footnote omitted).

${ }^{249}$ An explicit grant of interpretive power exists when a statute uses language like "as defined by agency rule" when referring to a statutory term.

${ }^{250}$ Perhaps it would be better to distinguish here between interpretative power and lawmaking power. Cf. Harper, supra note 54, at 213-14 (“[C]ourts should not allow the Board to distinguish between Congress's implicit delegation of lawmaking power through the use of ambiguous statutory language, and the more explicit delegation of discretion as expressed in the Act's grant of rulemaking authority. The exercise of both these formally distinct forms of discretion requires the Board to make policy decisions, and in doing so to consider the impact on actual labor relations." (footnote omitted)). 
capricious test. Further, when an agency fills a statutory gap, whether power to fill the gap has been explicitly granted or not, the agency's action should be evaluated using the same standard, i.e., whether the agency has exceeded its statutory authority and whether the chosen course of action is arbitrary, capricious, an abuse of discretion, or otherwise not in accordance with law. There is nothing in either of these pre-Chevron standards that is so deferential that they should apply only when Congress has explicitly granted lawmaking power to the administering agency.

The biggest question that arises over the use of pre-Chevron standards is whether it is consistent with the APA's assignment to reviewing courts of the responsibility to decide all questions of law. This Article has argued that the extremely deferential version of Chevron is inconsistent with the APA, but what about the modified pre-Chevron practice proposed above?

Although it is a close question, it does not appear that the pre-Chevron regime is inconsistent with the APA's judicial review provisions. At least it is not as inconsistent as Chevron. The clearest inconsistency between Chevron and the APA was that under original directly spoken Chevron, the reviewing court would become hyper-deferential whenever Congress had not "directly spoken to the precise question at issue." 251 Under the preChevron regime, when a statute was ambiguous, the Court either interpreted the statute itself $^{252}$ or it determined whether the agency's interpretation was "reasonable" in light of the statute's language, policy, and legislative history. This is not quite independent judicial determination of the meaning of the statute, but it is pretty close. PreChevron, reviewing courts did not step aside whenever the statute failed to provide a clear answer to the precise question at issue.

The question is even closer with regard to the pre-Chevron regime that governed review of statutory gaps. In such instances, the cases seem to leave the formulation of a legal standard to the agency, subject to judicial review to make sure that the agency did not go beyond delegated power or adopt a legal standard that was arbitrary, capricious, an abuse of discretion, or otherwise not in accordance with law. Is it inconsistent with the APA for the reviewing court to allow the agency to fill the statutory gap? In my view, it cannot be, for the simple reason that if Congress has truly delegated the power to fill a gap to an agency, then the reviewing court applying the pre-Chevron standard is respecting that delegation, i.e., it is following the law as laid down by Congress. As long as the courts are not overly creative in finding gaps and delegations to agencies, then the reviewing court correctly resolves the question of statutory construction by respecting the delegation of lawmaking authority to the agency. The only

${ }^{251}$ Chevron U.S.A., Inc. v. NRDC, 467 U.S. 837, 842 (1984).

${ }^{252}$ See Indus. Union Dep't, AFL-CIO v. Am. Petroleum Inst., 448 U.S. 607, 641-44, 651-53 (1980); Citizens to Pres. Overton Park, Inc., v. Volpe, 401 U.S. 402, 411-14 (1971). 
reservation in re-adopting pre-Chevron practice is that reviewing courts should overturn agency action whenever it is "not in accordance with law," not only when it is "patently" or "manifestly" contrary to law. That level of deference to agency legal determinations is inconsistent with the APA's assignment of statutory questions to reviewing courts.

This regime is preferable to the Chevron regime for many reasons. All of the controversy over whether Chevron applies, and if so how, would fade away. Courts and parties would no longer need to spend inordinate amounts of time and energy on Chevron and could focus their attention where it really should be, on questions of statutory meaning and administrative policy. Given the abject failure of Chevron to simplify judicial review of statutory interpretation, the messier outward appearance of pre-Chevron practice should not be a deterrent to returning to it.

One significant objection to abandoning Chevron Step Two is that the flexibility that allows agencies to alter their interpretations will be lost. But this is not necessarily so. There is no reason why the Court, in overruling or abandoning Chevron, could not preserve that flexibility by clarifying that when a court finds agency statutory interpretation to be reasonable or within delegated authority, the reviewing court does not ordinarily foreclose the possibility that an agency might, in the future, adopt a different interpretation that could also be reasonable or within delegated authority. ${ }^{253}$ The Court has already done this with noninterpretive policy decisions, rejecting a heightened standard of review under the arbitrary, capricious standard when an agency changes its policy. ${ }^{254}$ The Court did this without citing Chevron even though the case involved the application of a statutory provision. ${ }^{255}$ The Court reviewed the agency's policy under the arbitrary and capricious standard rather than Chevron, and concluded that there is no heightened standard of review when an agency changes its policy. ${ }^{256}$

Of course, if the reviewing court finds that there is only one permissible construction of a statute, then the court should declare so and the agency would have no flexibility to change to a different interpretation. This is the practice under Chevron Step One, and it too would not necessarily change if Chevron were overruled.

Even if the conclusion is that pre-Chevron practice is inconsistent with

\footnotetext{
${ }^{253}$ Whether this is consistent with the APA is discussed in the following paragraphs.

${ }^{254}$ FCC v. Fox Television Stations, Inc., 129 S. Ct. 1800, 1810 (2009).

255 The case involved the agency's enforcement of the statutory ban on obscene, profane, and indecent language between the hours of 6 a.m. and 10 p.m. The FCC was granted the authority to enforce the ban through fines, license denials, and license revocation. After years of apparently contrary practice, the FCC decided in 2004 that a single use of certain words violated the ban, and the Court upheld that change in policy as not arbitrary or capricious. Id. at 1806-08.

${ }^{256}$ As noted above, the Court relied on Vermont Yankee for the proposition that it was not free to impose a more stringent standard of review to agency action involving a change in policy. Supra note 55 and accompanying text.
} 
the APA, moving back to it would be an improvement from the current situation since Chevron is even more inconsistent with the APA. If, however, these pre-Chevron forms of deference are viewed as too great a departure from the APA, it seems that the most likely replacement for Chevron would be Skidmore deference, under which reviewing courts resolve questions of law with more or less attention to agency views, depending on the situation. Although, for reasons enumerated below, this would not be an attractive option, it would be superior to the Chevron regime, if only because it would eliminate all of the arguing over whether Chevron applies and the uncertainty over which version of Step One the reviewing court will apply in a particular case.

Under Skidmore deference, as it has been practiced, reviewing courts take into account numerous factors in determining how much deference to afford agency interpretations. These factors include the procedural formality used by the agency, the consistency of the agency's interpretation over time, the level at which the decision was made within the agency, the apparent thoroughness of the agency's consideration of the matter, the relevance of agency expertise to the matter, and the apparent validity of the agency's reasoning. ${ }^{257}$ In one sense, Skidmore is much more straightforward than Chevron because Skidmore does not include multiple steps and multiple versions. But it is a very open-ended inquiry and if the degree of deference appeared important, litigants and courts would end up expending a great deal of effort mapping each case into the Skidmore framework. To some, Skidmore is no deference at all-the reviewing court goes along with the agency when, all things considered, it agrees with the agency. ${ }^{258}$ For these reasons, a more constrained, certain doctrine is preferable to Skidmore.

Another issue is whether agencies could maintain the flexibility to alter their statutory interpretations under either pre-APA practice or Skidmore. Justice Scalia has argued that Skidmore was inferior to Chevron Step Two because under Skidmore the ultimate interpretive decision is made by the reviewing court and thus could not be altered by the agency. ${ }^{259}$ This is an accurate depiction of practice under Skidmore-reviewing courts under Skidmore arrive at what they consider the correct interpretation while taking into account the agency's views. There is nothing, however, in the nature of Skidmore deference or deference under pre-APA practice that makes this so. A court could pronounce an interpretation as within the

${ }^{257}$ Skidmore v. Swift \& Co., 323 U.S. 134, 139-40 (1944).

${ }^{258}$ See Panel, Agency Preemption: Speak Softly, but Carry a Big Stick?, 11 CHAP. L. REV. 363, 381-82 (2008) (comments of Ronald A. Cass, at the 2006 Federalist Society's National Lawyer's Convention) (“[T]hat's why the notion of Skidmore deference is a wonderful concept for courts, which means that they do what the agency says when they would've done it without the agency doing it anyway.”).

${ }^{259}$ United States v. Mead Corp., 533 U.S. 218, 247 (2001) (Scalia, J., dissenting). 
range of possible interpretations without precluding the agency from adopting another interpretation. ${ }^{260}$ Similar to current practice, this would depend on the degree of deference involved in the particular case. A reviewing court could explicitly note when an interpretation is open to future revision by the agency and when it is not, ${ }^{261}$ perhaps with a presumption in favor of revision to govern those cases in which the court fails to note the issue. ${ }^{262}$

This flexibility might still, however, be viewed as inconsistent with the APA's apparent assignment of interpretive authority to reviewing courts. As discussed above, it was the narrowness of Step One and its view that all ambiguity amounted to an implicit delegation of interpretive power that rendered original Chevron inconsistent with the APA. Under original Chevron, it was likely that the reviewing court would rarely find that Congress had directly spoken to the precise question at issue, which meant that the vast majority of cases would be decided in the hyper-deferential Step Two. This seemed, in light of the language of the APA, to be too small a domain for congressional intent. It is also arguable that allowing an agency to change the meaning of a statute is similarly inconsistent with the APA's meaning. In my view, if the reviewing court concludes that a statute can bear a range of meanings, then the court discharges its duty under the APA by confining the agency to interpretations within that range. There is merit, however, to the contrary view, and it may be that if Chevron is overruled due to its inconsistency with the APA, then one cost of that action would be that agencies hoping to alter their statutory interpretations would need to persuade courts to allow them to do so under normal stare decisis standards rather than more flexible standards relating to judicial review of agency interpretation. At a minimum, courts should be open to concluding that there is a best answer in an interpretive controversy that the agency and the reviewing court are bound to follow.

\section{CONCLUSION}

After twenty-five years of bitter experience, the Supreme Court should admit that the Chevron experiment has failed. Chevron is inconsistent with

\footnotetext{
${ }^{260}$ See Richard Murphy, A New Counter-Marbury: Reconciling Skidmore Deference and Agency Interpretive Freedom, 56 ADMIN. L. REV. 1, 7 (2004) (arguing that agencies should be free under Skidmore to alter statutory interpretation; prior interpretation should be one factor considered under Skidmore standard).

${ }^{261}$ I do not mean that the correct interpretation is absolutely not subject to revision by the agency, but rather that ordinary principles of stare decisis apply and thus the agency would have to convince the reviewing court to overrule its prior decision in such cases. Reviewing courts should be somewhat more open to overruling when the agency charged with administering the statute argues for a different interpretation, especially if circumstances have changed or if experience under the prior interpretation has revealed problems.

${ }^{262}$ The reason the presumption would be in favor of revision is to give the courts an incentive to identify the cases in which revision would be governed by ordinary stare decisis principles.
} 
the APA, has not accomplished its apparent goals of simplifying judicial review and increasing deference to agencies, and has instead spawned an incredibly complicated regime that serves only to waste litigant and judicial resources. Pre-Chevron practice was more sensible and easier to administer. Barring an admission of complete failure, a simplified regime constructed without the fictional invocation of congressional intent to delegate interpretive power whenever a statute is ambiguous would be more consistent with the APA and the traditional role of courts in judicial review of agency action. It would also be easier to administer, and more consistent with the values upon which Chevron itself was supposed to be based. The sooner the Court throws in the towel on Chevron, the better. 